\title{
Reviews and syntheses: How do abiotic and biotic processes respond to climatic variations in the Nam Co catchment (Tibetan Plateau)?
}

\author{
Sten Anslan ${ }^{1,2}$, Mina Azizi Rad ${ }^{2,3}$, Johannes Buckel ${ }^{4}$, Paula Echeverria Galindo ${ }^{2}$, Jinlei Kai ${ }^{5,6}$, Wengang Kang ${ }^{2}$, \\ Laura Keys $^{7}$, Philipp Maurischat ${ }^{8}$, Felix Nieberding ${ }^{2,9}$, Eike Reinosch ${ }^{10}$, Handuo Tang ${ }^{5,6}$, Tuong Vi Tran ${ }^{11}$, \\ Yuyang Wang ${ }^{5,6}$, and Antje Schwalb ${ }^{2}$ \\ ${ }^{1}$ Zoological Institute, Technische Universität Braunschweig, Mendelssohnstr. 4, 38106 Braunschweig, Germany \\ ${ }^{2}$ Institute of Geosystems and Bioindication, Technische Universität Braunschweig, \\ Langer Kamp 19C, 38106 Braunschweig, Germany \\ ${ }^{3}$ Max Planck Institute for Biogeochemistry, 07745 Jena, Germany \\ ${ }^{4}$ Institute for Geophysics and Extraterrestrial Physics, Technische Universität Braunschweig, \\ Mendelssohnstraße 3, 38106 Braunschweig, Germany \\ ${ }^{5}$ Key Laboratory of Tibetan Environment Changes and Land Surface Processes, Institute of Tibetan Plateau Research, \\ Chinese Academy of Sciences, Beijing, China \\ ${ }^{6}$ University of Chinese Academy of Sciences, Beijing, China \\ ${ }^{7}$ Institute for Geography, Friedrich-Schiller-Universität Jena, Löbdergraben 32, 07743 Jena, Germany \\ ${ }^{8}$ Institute of Soil Science, Leibniz Universität Hannover, Herrenhäuser Str. 2, 30419 Hanover, Germany \\ ${ }^{9}$ GFZ German Research Centre for Geosciences, Telegrafenberg, 14473 Potsdam, Germany \\ ${ }^{10}$ Institute of Geodesy and Photogrammetry, Technische Universität Braunschweig, \\ Bienroder Weg 81, 38106 Braunschweig, Germany \\ ${ }^{11}$ Institute of Fluid Mechanics and Environmental Physics in Civil Engineering, Leibniz Universität Hannover, \\ Appelstraße 9A, 30167 Hanover, Germany
}

Correspondence: Felix Nieberding (f.nieberding@tu-braunschweig.de)

Received: 5 February 2019 - Discussion started: 20 March 2019

Revised: 5 February 2020 - Accepted: 6 February 2020 - Published: 6 March 2020

\begin{abstract}
The Tibetan Plateau (TP) is the largest alpine plateau on Earth and plays an important role in global climate dynamics. On the TP, climate change is happening particularly fast, with an increase in air temperature twice the global average. The particular sensitivity of this high mountain environment allows observation and tracking of abiotic and biotic feedback mechanisms. Closed lake systems, such as Nam Co on the central TP, represent important natural laboratories for tracking past and recent climatic changes, as well as geobiological processes and interactions within their respective catchments. This review gives an interdisciplinary overview of past and modern environmental changes using Nam Co as a case study. In the catchment area, ongoing rise in air temperature forces glaciers to melt, contributing to a rise in lake level and changes in water chemistry. Some studies base their conclusions on inconsistent glacier inventories, but an
\end{abstract}

ever-increasing deglaciation and thus higher water availability have persisted over the last few decades. Increasing water availability causes translocation of sediments, nutrients and dissolved organic matter to the lake, as well as higher carbon emissions to the atmosphere. The intensity of grazing has an additional and significant effect on $\mathrm{CO}_{2}$ fluxes, with moderate grazing enhancing belowground allocation of carbon while adversely affecting the $\mathrm{C}$ sink potential through reduction of above-surface and subsurface biomass at higher grazing intensities. Furthermore, increasing pressure from human activities and livestock grazing are enhancing grassland degradation processes, thus shaping biodiversity patterns in the lake and catchment. The environmental signal provided by taxon-specific analysis (e.g., diatoms and ostracods) in Nam Co revealed profound climatic fluctuations between warmer-cooler and wetter-drier periods since the late 
Pleistocene and an increasing input of freshwater and nutrients from the catchment in recent years. Based on the reviewed literature, we outline perspectives to further understand the effects of global warming on geodiversity and biodiversity and their interplay at Nam Co, which acts as a case study for potentially TP-level or even worldwide processes that are currently shaping high mountain areas.

\section{Introduction}

The Tibetan Plateau (TP), often referred to as "The Third Pole" and "The Water Tower of East Asia", is the highest and largest alpine plateau on Earth (Qiu, 2008). With an area of about 2.5 million $\mathrm{km}^{2}$ at an average altitude of $>4000 \mathrm{~m}$ above sea level (a.s.1.), it includes the entire southwestern Chinese provinces of Tibet and Qinghai; parts of Gansu, Yunnan, and Sichuan; and neighboring countries (Fig. 1). The southern and eastern plateau and the adjacent Himalayas regions form the headwaters of several major rivers (i.e., Brahmaputra, Ganges, Hexi, Indus, Mekong, Salween, Yangtze, and Yellow rivers), providing freshwater for $\sim 1.65$ billion people and many ecosystems in greater Asia (Cuo and Zhang, 2017). Large proportions of the inner TP are endorheic and therefore do not drain into the large river systems. On the TP, the effects of climate change are expressed more strongly than the global average, showing a steep rise in air temperature of about $0.3^{\circ} \mathrm{C}$ per decade since 1960 (Yao et al., 2007) and a moderate rise in precipitation during the last few decades (Dong et al., 2018). The warming rate increases with altitude (Pepin et al., 2015), which is why the air temperature on the TP is soaring roughly twice the global average, thus substantially affecting the geodiversity and biodiversity. Glaciers and lakes are the dominant components for the Tibetan water sources, and their actual status and future development are strongly impacted by global warming. Since the 1990s, nearly all glaciers on the TP have exhibited retreat, causing a $5.5 \%$ increase in river runoff from the Tibetan Plateau (Yao et al., 2007). The consequences of deglaciation and permafrost degradation (Wu et al., 2010) are observable in higher water and sediment fluxes, relief changes and arising natural hazards (floods, rockfalls, landslides, desertification, ecosystem degradation). Consequently, landscapes are continuously being rearranged which alters the spatial distribution and composition of the inhabiting species, many of which are endemic to the TP (Walther et al., 2002). Even conservative estimates predict substantial species extinction and considerable changes to the ecosystems (Chen et al., 2011; Bellard et al., 2012). The future trajectory of such complex processes is difficult to map accurately, thus it is important to monitor the current state as well as the evolution of this highly sensitive region. The large number of water bodies on the TP and its geological diversity, climatic setting and sensitivity to climate change make it a unique natural labo- ratory, which could be used as an early warning system for other alpine environments. Many lakes on the TP are superficially closed systems, which is why they are particularly suitable as "thermometers" and "rain gauges" to measure the climatic, hydrological, geomorphological, pedological and ecological changes in their respective catchments. With an area of $2018 \mathrm{~km}^{2}$, Nam Co is the second largest lake on the central TP. Currently, Nam Co represents an endorheic system, acting as a sink for water, sediment and carbon fluxes. The existence of a former drainage ("Old Qiangtang Lake") towards northwestern Siling Co and further east down from the TP is still under discussion (Li et al., 1981; Kong et al., 2011) (see Sect. 3.1). With good accessibility and infrastructure such as the Nam Co Monitoring and Research Station for Multisphere Interactions (NAMORS), the Nam Co catchment has become a frequent study location for monitoring and tracking of environmental changes over various timescales.

Here we present an interdisciplinary overview of how Earth surface fluxes have developed with changing environmental conditions and which consequences are to be expected for biodiversity, as well as for water, sediment and carbon fluxes within the study area of the Nam Co catchment on the central TP. In particular, this review considers past and modern geobiodiversity changes with a focus on glacier retreat in relation to hydrological patterns and changes in lake water chemistry. The corresponding changes in terrestrial ecosystems concerning carbon cycle, greenhouse gas releases and pasture degradation are discussed. We provide an overview of how the paleoenvironment on the Tibetan Plateau with respect to landscape evolution around Nam Co was shaped by geodiversity, lake level changes and Holocene vegetation cover. Lastly, based on the available studies, this review identifies the major research gaps that are awaiting further exploration and comparison with other high-altitude environments.

\section{Environmental changes in Nam Co and its catchment}

\subsection{Climatic characteristics of the Nam Co basin}

The prevailing climate at Nam Co is characterized by strong seasonality, with long, cold winters and short but moist summers. During winter, the westerlies control the general circulation and lead to cold and dry weather, with daily temperature minima below $-20^{\circ} \mathrm{C}$. In springtime, the TP heats up and allows the meltwater to percolate to deeper soil layers. The drought situation increases gradually until the monsoon rains arrive, typically between May and June. During autumn, weather shifts again to clear, cold and dry conditions (Yao et al., 2013). The mean annual temperature measured at the NAMORS research station (Fig. 1) between 2006 and 2017 was $-0.6^{\circ} \mathrm{C}$, and the annual precipitation was between $291-568 \mathrm{~mm}($ mean $=406 \mathrm{~mm})$, with the majority occurring during the monsoon season from May to October 

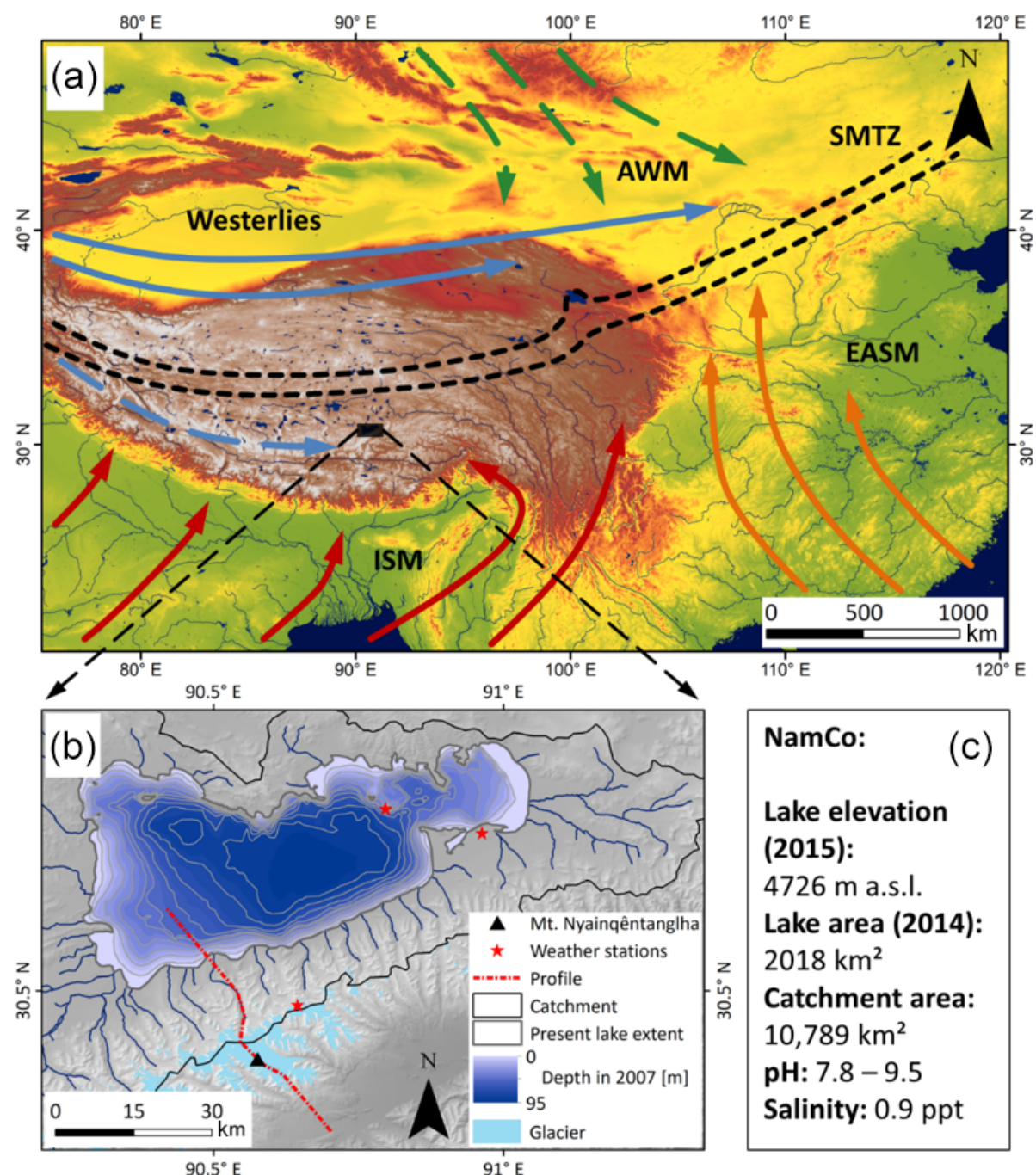

Figure 1. Major atmospheric systems governing the climate in China (a). The Nam Co study site (b). Characteristics of Nam Co's catchment (c). (a) Continuous arrows indicate systems active in summer. These are the Indian Summer Monsoon (ISM) in red, the East Asian Summer Monsoon (EASM) in orange and the westerlies in blue. Dashed arrows represent systems active in winter. These are the Asian Winter Monsoon (AWM) in green and southern parts of the westerlies in blue. The dotted black lines denote the Summer Monsoon Transition Zone (SMTZ) (following Wünnemann et al., 2018). Background elevation data according to SRTM digital elevation model v4 (Jarvis et al., 2008). (b) Nam Co catchment, including the current lake extent (based on Copernicus Sentinel data 2018, processed by ESA), its bathymetric depth in 2007 (Wang et al., 2009a), the outline of the catchment (following Keil et al., 2010), glaciers of the Nyainqêntanglha Range (GLIMS and NSDIC 2005, updated 2018) and rivers discharging into Nam Co (SRTM digital elevation model v4; Jarvis et al., 2008). The dotted red line indicates the profile position of Fig. 2. (c) Characteristics of Nam Co: lake elevation (Jiang et al., 2017), lake surface area (Zhang et al., 2017), catchment area, lake pH and salinity (Keil et al., 2010).

(Table 1). The onset and strength of monsoonal precipitation varies substantially between individual years and can be delayed by up to 6 weeks, depending on the altitude and latitude on the TP (Miehe et al., 2019). Precipitation rates are subject to spatial variations due to the $>7000 \mathrm{~m}$ high Nyainqêntanglha range, which represents the southern border of the lake catchment. This leads to considerably larger glacial areas in the southwestern area $\left(\sim 700 \mathrm{~km}^{2}\right)$ than in the northeastern area of the mountain range $\left(\sim 100 \mathrm{~km}^{2}\right)$ (Bolch et al., 2010).

\subsection{Glacier retreat and hydrological patterns of Nam Co}

The rise of satellites such as Envisat, CryoSat, and ICESat and the increasingly widespread availability of their data has enabled the accurate study of lake and glacier parameters as far back as the early 1970s (Wu and Zhu, 2008; Zhu et al., 2010b; Liao et al., 2013). The size of Nam Co and the extent and distribution of glaciers in the Nyainqêntanglha range have been the subject of many publications over the recent 
Table 1. Average daily air temperature (maximum, mean and minimum in ${ }^{\circ} \mathrm{C}$ ) and average daily precipitation (sum in mm) from NAMORS from 2006 to 2017. Calculations were performed using the tidyverse package family in R on RStudio environment (Wickham, 2017; RStudio Team, 2018; R Core Team, 2019). Data provided by ITP Beijing; for details about sensor equipment, see Ma et al. (2009).

\begin{tabular}{lrrrrrrrrrrrrr}
\hline & Jan & Feb & Mar & Apr & May & Jun & Jul & Aug & Sep & Oct & Nov & Dec & $\varnothing / \sum$ \\
\hline$T_{\max }$ & -0.7 & -1.5 & 1.5 & 4.7 & 11.6 & 13.3 & 12.6 & 12.2 & 11.3 & 8.7 & 2.5 & 1.2 & 6.4 \\
$T_{\text {mean }}$ & -10.8 & -9.7 & -5.7 & -1.4 & 3.1 & 7.9 & 9.1 & 8.3 & 6.5 & 0.3 & -6.5 & -8.4 & -0.6 \\
$T_{\min }$ & -21.5 & -20.5 & -14.3 & -7.3 & -4.5 & 1.1 & 5.2 & 3.2 & -1.3 & -14.7 & -15.3 & -19.1 & -9.1 \\
Precip. & 4 & 1 & 3 & 13 & 23 & 41 & 85 & 117 & 81 & 34 & 5 & 1 & 406 \\
\hline
\end{tabular}

years (Yao et al., 2007; Frauenfelder and Kääb, 2009; Bolch et al., 2010; Wang et al., 2013; Fig. 2; Table 1). Due to different data sources with varying resolutions as well as different mapping procedures, the estimated glacier area varies between different studies (Fig. 2; Table 1), as the delineation of debris- and snow-covered glaciers is rather subjective $(\mathrm{Wu}$ et al., 2016). This is especially true for the first glacier inventory (Li et al., 2003 in Bolch et al., 2010), which has been discussed in various studies due to inaccuracies and the quality of its base data (Frauenfelder and Kääb, 2009; Bolch et al., 2010). Nevertheless, recent studies show glacier shrinkage in the Nyainqêntanglha range at a rate of $0.3 \%-0.5 \% \mathrm{yr}^{-1}$, as measured since 1970 when the first satellite images were acquired (Fig. 2; Table 1). As a result of this glacier melting, the lake surface area has expanded from ca. $1930 \mathrm{~km}^{2}$ to ca. $2018 \mathrm{~km}^{2}$ at a rate of $2.1 \mathrm{~km}^{2} \mathrm{yr}^{-1}$ (Fig. 3a), and the lake level rose at a rate of $0.3 \mathrm{~m} \mathrm{yr}^{-1}$ until approximately 2009 and at lower rates since then (Fig. 3b). The initial rising trends of both lake level and surface area are mirrored by most lakes in the southern part of the TP, but the slowdown of this trend observed at Nam Co around 2009 seems unique (Jiang et al., 2017). This suggests that the lakes on the TP react to changing environmental parameters in a variety of different ways, and that geographical proximity among lakes does not necessarily produce similar reactions to change. The effects on freshwater input to the lake are discussed in Sect. 2.3. Although changes in monsoonal precipitation and wind direction may influence glacial retreat rates (Wang et al., 2013), rising temperatures remain their primary cause (Ji et al., 2018). The total contribution of glacial meltwater as surface runoff to this lake level increase has been estimated as ranging from $10 \%$ to $53 \%$ (Zhu et al., 2010b; Lei et al., 2013; Wu et al., 2014; Li and Lin, 2017), with recent studies being at the lower end of this spectrum. Increased precipitation is estimated to be responsible for $50 \%-70 \%$ of lake growth (Zhu et al., 2010b; Lei et al., 2013). Whether there is a change in evaporation remains unclear, as studies for approximately the same time period have suggested both a slightly increasing and a slightly decreasing evaporation rate since the late 1970s (Lazhu et al., 2016; Ma et al., 2016).

The rises in temperature and precipitation are also affecting permafrost soils that extend over an area of ca. 1.4 million $\mathrm{km}^{2}$ (Yang et al., 2004) on the TP. The permafrost layers can be described as relatively warm and thin, with temperatures mostly $>-1.5^{\circ} \mathrm{C}$ and $<100 \mathrm{~m}$ thickness (Wu et al., 2010). The mean annual soil temperature of permafrost in particular areas of the TP has increased by $0.1-0.3^{\circ} \mathrm{C}$ between 1970 and 1990 (Cheng and $\mathrm{Wu}, 2007$ ). Simulation studies have shown that due to climate warming the permafrost extent may decrease by $9 \%-19 \%$ by 2049 and by $13 \%-58 \%$ by 2099 (Li and Cheng, 1999; Nan, 2005). Although there is no clear estimate of permafrost extent in the Nam Co basin, Tian et al. (2009) reports a lower limit of permafrost at an elevation around $5300 \mathrm{~m}$ a.s.l. along the northern slopes of Mt. Nyainqêntanglha (7162 m). A frost lens was also encountered $9 \mathrm{~m}$ below the surface ( $4738 \mathrm{~m}$ a.s.l.) while sampling an outcrop along the right bank of the Gangyasang Qu close to the northwestern lake shore in 2005 (Schütt et al., 2010). Thus, due to increasing temperatures, permafrost degradation may serve as an additional recharge factor to groundwater, resulting in increased subsurface inflow into the lakes.

Focusing on Nam Co, the hydraulic interaction between lake and groundwater is still uncertain, as previous studies either neglected or ignored the influence of groundwater due to a lack of reliable data (Zhang et al., 2011). However, recent studies revealed a water imbalance, which was explained by lake water seepage with an estimated outflow of $1.9 \times 10^{9}$ and $1.5 \times 10^{9} \mathrm{~m}^{3}$ during 1980-1984 and 1995-2009, respectively (Zhou et al., 2013; Du et al., 2018).

\subsection{Enhanced water availability controls changes in lake water chemistry}

The maximum recorded depth of Nam Co is $122 \mathrm{~m}$ (Li et al., 2008a), with brackish water characterized by an alkaline $\mathrm{pH}$ of 7.8-9.5 and a conductivity of $1920 \mu \mathrm{S} \mathrm{mm}^{-1}$ (Keil et al., 2010). The chemical composition of a lake is essentially a function of its climate (which affects its hydrology) and the basin geology. Increased freshwater input from precipitation, melting glaciers and thawing permafrost alters the chemical composition of the lake water and enhances surface runoff, infiltration rates and subsurface flow. Together with the input of freshwater, streams transport dissolved organic matter (DOM), which is composed of a wide range of dissolved components and particles $(\leq 0.45 \mu \mathrm{m})$, thus affecting the water chemistry in the lake (Spencer et al., 2014). Excessive 
Table 2. Overview of glacier area changes (\%) in the western Nyainqêntanglha range (changed after Wu et al., 2016).

\begin{tabular}{llrl}
\hline Period & $\begin{array}{l}\text { Region of the Nyainqêntanglha } \\
\text { range }\end{array}$ & $\begin{array}{r}\text { Glacier } \\
\text { shrinkage (\%) }\end{array}$ \\
\hline $1970-2000$ & Southeastern slope & -5.2 & Shangguan et al. (2008) \\
$1970-2000$ & Northwestern slope & -6.9 & Shangguan et al. (2008) \\
$1970-2000$ & Western & -5.7 & Shangguan et al. (2008) \\
$1977-2010$ & Western & $-22.4 \pm 2.9$ & Wang et al. (2013) \\
$1970-2009$ & Western & $-21.7 \pm 3.4$ & Wu et al. (2016) \\
$1970 / 80-2000$ & Southwestern & -19.8 Frauenfelder and Kääb (2009) \\
$1970-2000$ & Nam Co basin & -15.4 & Wu and Zhu (2008) \\
$1976-2001$ & Nam Co basin & $-6.8 \pm 3.1$ & Bolch et al. (2010) \\
$1976-2001$ & Southeastern slope & $-5.8 \pm 2.6$ & Bolch et al. (2010) \\
$1976-2009$ & Detailed glaciers: Zhadang, Tangse No. 2, Lalong, Xibu, Panu & $-9.9 \pm 3.1$ & Bolch et al. (2010) \\
\hline
\end{tabular}

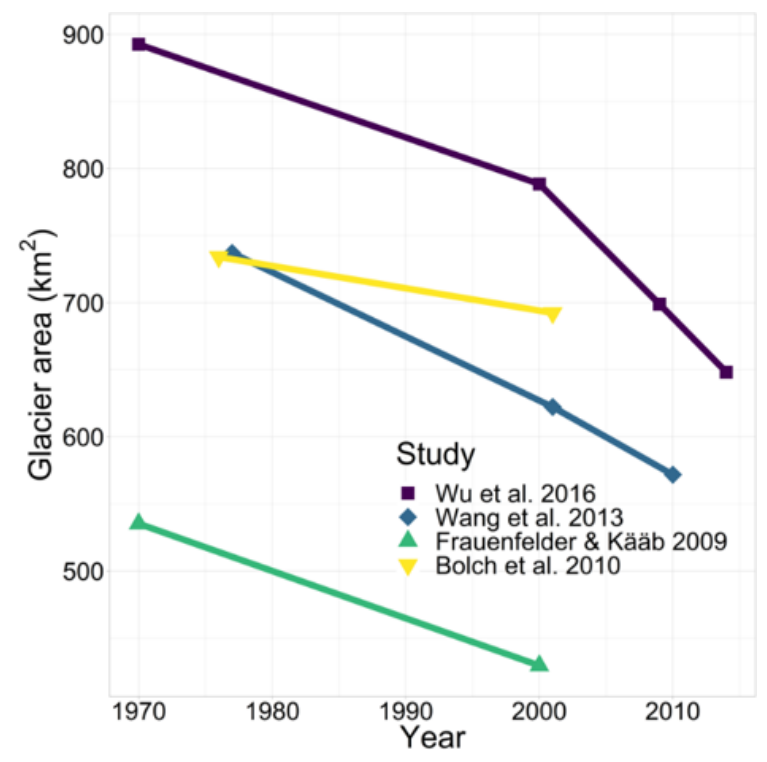

Figure 2. Glacier area reduction in the southwestern Nyainqêntanglha range since 1970 as evaluated in various studies.

landscape disturbance through removing vegetative cover causes higher rates of DOM leaching, more erosion and increasing water runoff velocity, resulting in additional input of minerals and nutrients into the lake. Since the process of DOM leaching and translocation itself is largely dependent on water and sediment cycles (Kaiser and Kalbitz, 2012), it represents both the seasonal and interannual variation in an ecosystem as well as its long-term trend. As the glaciers on the TP retreat, highly bioavailable DOM may provide additional nutrients to downstream environments and amplify the trend of eutrophication of lotic and lacustrine ecosystems. Furthermore, the rivers on the TP have been shown to transport dissolved organic carbon from thawing permafrost areas (Qu et al., 2017), which is likely rapidly degraded via microbial activity, resulting in $\mathrm{CO}_{2}$ emissions, thus potentially producing a positive feedback on global warming. However, the research into DOM as an important allochthonous source of nutrients and as a capture of biodiversity and geodiversity of its respective catchment area is largely lacking for High Asia. The concentration and ratios of different ions in the water have a regulatory impact on the structure of biotic communities (microbes, invertebrates and fish) that can best tolerate abiotic conditions (Wrozyna et al., 2012). In Nam Co, water conductivity has been regarded as the most important environmental factor for shaping communities such as archaea, bacteria, phytoplankton, and micro-invertebrates (Hu et al., 2010; Wang et al., 2011). Studies demonstrated that ammonia-oxidizing archaea (autotrophic microorganisms) are key contributors to ammonia oxidation in deep and oligotrophic lakes (Callieri et al., 2016). This has implications for $\mathrm{CO}_{2}$ fixation in the hypolimnion or the benthic zone, where there is insufficient irradiance to support photosynthesis, implying that archaea would perform the final step in the decay of organic matter via methanogenesis, resulting in carbon dioxide accumulation (e.g., when they decrease during winter). Although nitrification does not directly change the inventory of inorganic nitrogen in freshwater ecosystems, it constitutes the only known biological source of nitrate and as such represents a critical link between mineralization of organic $\mathrm{N}$ and its eventual loss as $\mathrm{N}_{2}$ by denitrification or anaerobic ammonia oxidation to the atmosphere (Herber et al., 2020). Ultimately, the changes in the communities of primary producers could alter the lake's trophic structure, which also affects the top predators of the ecosystem. The primary productivity, as an indicator of nutrient supply and a longer growing period associated with a shorter ice cover duration, has increased markedly at Nam Co within the last 100 years (Lami et al., 2010). Wang et al. (2011) reported the increasing abundance of the diatom species Stephanodiscus minutulus during the last few decades (ca. 1970-2001). This species is generally viewed as an indicator of water phosphorus enrichment, suggesting increasing inputs from the lake's catchment and stronger mixing in spring season. To predict future consequences of ongoing climate change, it is essential to understand the responses of biotic communities to hy- 
drological variations. Thus, long-term monitoring is needed to adequately address the feedbacks of recent environmental changes, while climatic conditions of the past can be reconstructed through the study of organisms such as diatoms and ostracods that are sensitive to hydrologic and chemical variations (see Sect. 3.2).

\subsection{Vegetation, soils and pasture degradation in the catchment}

Nam Co is located in the transitional zone between the central Tibetan Kobresia pygmaea pastures and the northwestern alpine steppe ecosystem (Miehe et al., 2019) (Fig. 4). Situated on the northern slope of the Nyainqêntanglha range, the vegetation pattern changes according to elevation, moisture availability and temperature. Grazing intensity and abundance of small rodents, such as the plateau pika (Ochotona curzoniae), may contribute to the shaping of the vegetation cover (Dorji et al., 2014; Miehe et al., 2014). The area close to the lake $(<4800 \mathrm{~m})$ is covered mainly with alpine steppe vegetation consisting of Artemisia, Stipa, Poa, Festuca and Carex (Li, 2018; Nölling, 2006). Soils developed in the drier steppe areas consequentially tend to show lower organic carbon contents, naturally lowering their total $\mathrm{C}$ sink or source potential, as indicated by a study from Ohtsuka et al. (2008). Only one evaluable soil investigation exists from the area of Nam Co. Wang et al. (2009b) investigated two lake terrace sites, situated in the alpine steppe biome. According to their findings, the soils reflect the cold semiarid climate of the area by showing low biologic activity, while the influence of physical weathering is dominant. The soils showed several decimeter-thick layers of loess in which mainly the A horizons were developed. Although only very sparse to moderate vegetation cover occurs, an almost $30 \mathrm{~cm}$ thick organic-rich topsoil with granular structure was developed there (Wang et al., 2009b). Further organic-rich buried horizons were found and dated in both profiles, showing phases of climatic conditions enabling the buildup of organic material related to warm wet periods in the past (before 2.4 and $1.6 \mathrm{ka} \mathrm{cal} \mathrm{BP}$ ) and interchanging with phases of erosion, leading to, e.g., sheet erosion and the formation of gullies and alluvial fans supposedly during colder periods. These results fit well to climate reconstructions presented in Sect. 3.3 of our review. In accordance with the World Reference Base for Soil Resources (WRB) classification, we propose that the soils described by Wang et al. (2009b) can be classified as Calcisols, as there is evidence of carbonate translocation.

Higher up the slope $(4800-5200 \mathrm{~m})$, the alpine steppe is replaced by Kobresia pygmea pasture. Wang et al. (2007) and Kaiser et al. (2008) investigated the relationship between plant communities and development of soil types on the High Asian Plateau and for pasture soils in the wider area. Vegetation strongly controls the input of organic material into the soil but beyond that also stabilizes fine materials $(<0.1 \mathrm{~mm})$ and governs the degree of chemical weathering.
The authors found soils with stronger signs of biologic activity and chemical weathering (e.g., Cambisols) associated with alpine pasture sites. Kobresia root mats are usually developed in up to $40 \mathrm{~cm}$ thick loess layers and form a distinctive felty horizon that protects against erosion. The genesis of this felty root mat is attributed to Kobresia pygmaea, since this shallow-rooted, small plant allocates most of its biomass belowground and is able to reproduce vegetatively, making it well adapted to the high grazing pressure (Miehe et al., 2008). The curious dominance of $K$. pygmaea is often linked to grazing: (i) K. pygmaea replaces taller plants at sites where grazing pressure is increased experimentally. (ii) Several enclosures show that other grasses and shrubs increase in dominance after grazing competition ceased (Miehe et al., 2008). Hence, the felty root mat can be seen as an effect of an anthropozoogenic plagioclimax. At higher elevation (5200$5900 \mathrm{~m}$ ), only sparse alpine vegetation associated with initial soil processes occurs (Ohtsuka et al., 2008).

Where water availability is abundant, alpine swamps with Carex sagensis and Kobresia schoenoides are formed, especially at source areas, along riverbanks and in waterlogged depressions, some of which can cover large areas ( $\mathrm{Li}$ et al., 2011). Concerning soil development in alpine wetlands, the database is sparse compared to the alpine pasture and steppe biomes. It was pointed out for alpine pastures that a strong relationship exists between plant communities and (top)soil genesis. This relationship probably also holds true for alpine wetlands, with the exception that the influences of waterlogging and seasonal fluctuations and frost-melt cycles in the water table are likely to have an effect on soils. This can be expressed in terms of formation of gleyic features, frost turbations, heaves or other azonal features related to the soil-forming effects of water (Chesworth et al., 2008). It still needs to be clarified how these waterlogged areas affect the cycling and processing of organic matter and nutrients. There is no evidence of tree species, only the evergreen shrubs of Juniperus pingii var. wilsonii, which are mainly found on the south-facing slopes of the northern Nam Co catchment, and shrubs of Salix spp. in the Niyaqu Valley in the eastern lake catchment $(\mathrm{Li}, 2018)$. Alpine steppe is comprised of more plant species compared to pasture and marsh ecosystems, which are predominantly covered with Carex spp. and Kobresia spp. (Miehe et al., 2011b). Alpine pastures are often described as "golf-course-like" (Miehe et al., 2014) with the intention of illustrating their unique plane surface. However, small-scale structures such as thufa or hummocks are also present. The origin of these structures around Nam Co remains unclear; however, frost heave and permafrost degradation processes are seen to play a major role (Adamczyk, 2010). The landscape, generally dominated by endemic Kobresia pygmea sedges, harbors only a few other species (Miehe et al., 2019), but the additional microhabitats provided by thufa and hummocks enable rarer and less competitive species to settle in niches in these heterogeneous structures (Vivian-Smith, 1997). Compared to the surroundings, 

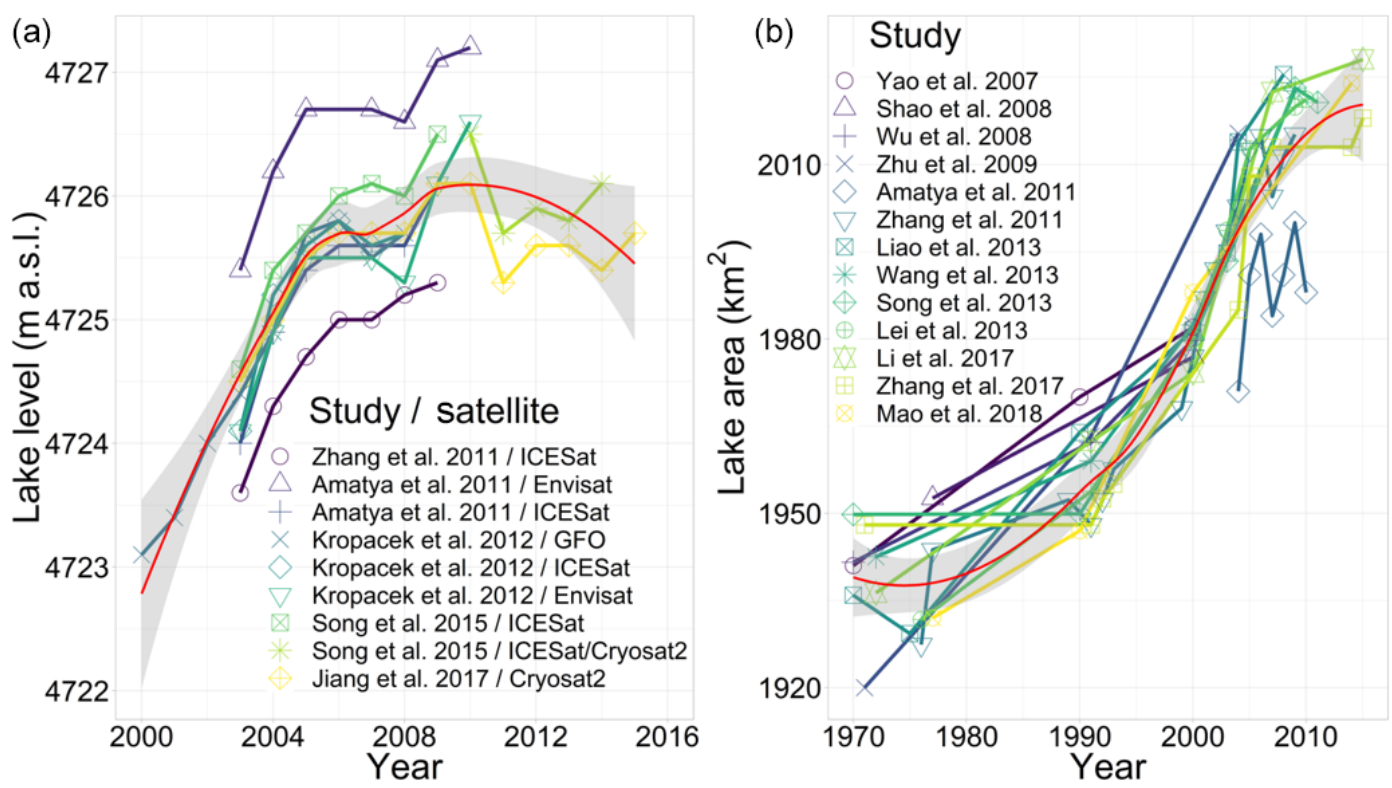

Figure 3. (a) Lake level changes of Nam Co since 2000 (there is notable shift in the water balance in 2009), and (b) changes of the lake surface area since 1970, as evaluated in previous studies. The overall increase rate of lake area is $2.1 \mathrm{~km}^{2} \mathrm{yr}^{-1}$. Red lines denote LOESS curves, with the $95 \%$ confidence interval shown in gray.

the microtopography of thufa possesses different degrees of wetness, exposition and insulation; depth of soil material; and type of topsoil. Local studies of the Nam Co area state that slightly degraded bare soil patches and gullies are often areas where plants have the chance to evade the suppression of the closed Kobresia pygmea root mat (Schlütz et al., 2007; Dorji et al., 2014). Thus, the genesis of thufa and mild, limited degradation processes are likely to increase species richness and diversity by cracking open the closed root mat of alpine pastures. These structures can also be formed by grass species that grown in tussocks (i.e., clumps, bunches or tufts), such as the endemic species Stipa purpurea (Liu et al., 2009) or Kobresia tibetica (Yu et al., 2010) and Kobresia schoenoides (Nölling, 2006).

The often-cited degradation of alpine pastures is likely initiated by natural polygonal cracking (Miehe et al., 2019), which can occur through drying (Velde, 1999) and then tends to be amplified by livestock trampling and plateau pikas using the cracks as highways (Liu et al., 2017b; Hopping et al., 2016). Overgrazing in alpine pastures is one of the most frequently mentioned causes of pasture degradation (Unteregelsbacher et al., 2012; Harris, 2010; Miehe et al., 2008), as excessive trampling by livestock might aggravate the initial conditions of polygonal cracking (Miehe et al., 2019). This effect, however, seems to be limited to the direct vicinity of herder's settlements and camps (piosphere centers), and many factors that are usually attributed to degradation are instead proof of environmental control, especially in drier areas (Wang et al., 2018b). Some researchers argue that climate change is the dominant or even sole driver of degradation (Wang et al., 2007), although the effects of rising temperatures and increasing precipitation appear to be an intensifier rather than the cause of degradation (Zhou et al., 2005; Harris, 2010). In turn, both Wang et al. (2018b) and Cao et al. (2019) point out that a multitude of effects might be in play, with a locally differing magnitude or even reversion, while usually moderate grazing was not found to cause degradation. Certainly there are more factors than just grazing pressure, and there might be site-specific effects leading to nonequilibrium behavior of the study object, be it pasture or steppe (Wang and Wesche, 2016). Plot-level experiments from the Nam Co area found warming to have significant effects on the shallow-rooted Kobresia pygmaea by reducing the number of flowers and delaying its reproductive phenology. These changes were provoked by simulating increasing precipitation by means of snow addition (Dorji et al., 2013) and also by maintaining a moderate level of grazing combined with snow addition (Dorji et al., 2018). This underlines the importance of climate forcing on the terrestrial systems in the Nam Co catchment. Grazing should not be seen as a disturbance but as an integral part of a non-steady-state but plagioclimax environment. Currently there are no estimates of the extent of degraded land at Nam Co, but the degradation of wide areas of alpine pastures is not without consequences for pastoralist communities. The severe degradation and sloughing off of the whole topsoil removes the basis for business and might lead to unknown consequences for the lake ecosystem by means of enhancing or terminating nutrient exchanges. The economic rationale of herders might be to increase the numbers of livestock, as this represents a form of 
social security (Simpson et al., 1994). The bottom line is that conflicts arise as less land is available for grazing (Hopping et al., 2016).

The Chinese government has favored policies such as sedentariness and fostered the construction of stationary settlements, which have, in turn, created hotspots of overgrazing (Miehe et al., 2008). In these hotspots, large portions of the topsoil are lost by erosion and denudation, leaving only an area of humic material or subsoil, thus being called "black beach" (Miehe et al., 2008) or "black-soil patch" (Liu et al., 2017a). The remaining landscapes are usually dry, poor in plant cover and prone to further degradation. Increasing areas of bare soil patches enhance evapotranspiration, causing earlier cloud cover formation, especially before noon. This may, in turn, lead to reduced radiation and temperature at the surface, thus hampering photosynthesis and consequently overall carbon sequestration (Babel et al., 2014). However, the evolution of grasslands on the TP has been accompanied by herbivore communities; thus, the plants have developed coping mechanisms to persist under continuous grazing pressure (Miehe et al., 2011a). According to the intermediate disturbance hypothesis, species diversity is higher under moderate disturbances, which suggests the positive effect of intermediate level of grazing pressure. Indeed, a plant clipping experiment to simulate grazing demonstrated that under the effect of climate warming, the grazing activities mitigated the negative effects of rising temperature by maintaining a higher number of plants (Klein et al., 2008). Many studies hold the traditional nomadic practice to be a sustainable one (Miehe et al., 2008; Babel et al., 2014; Hafner et al., 2012), but the current policy of removing pastoralist lifestyles from certain regions could potentially reduce overall species richness.

\subsection{Effects on carbon cycling in alpine ecosystems}

Changes in temperature and moisture have a significant effect on the biotic community structure with feedbacks on ecosystem productivity. Alpine meadows respond with increased plant productivity to warming, while productivity may be hampered in alpine steppe ecosystems (Ganjurjav et al., 2016). As soil moisture governs the community response to warming, negative effects of warming on plant productivity likely occur due to limited water availability (Ganjurjav et al., 2016). Warming was also reported to have a negative effect on plant species diversity in both alpine meadow and steppe ecosystems (Klein et al., 2008; Ganjurjav et al., 2016). Possible explanations for a decline in plant species diversity include changes in small mammal activity, storage of belowground nutrient resources and water stress and microclimate in general (soil temperature and moisture) (Ganjurjav et al., 2016; Klein et al., 2008, 2004). Thus, climate change may reduce the habitat quality for the local populations of grazers and reduce the well-being of the pastoralists by diminishing the abundance of palatable and medicinal plant groups. The changes in the plant productivity levels, as well as community changes, affect the local carbon cycle. Alpine grassland root mats on the TP are estimated to store up to $10 \mathrm{~kg}$ of carbon (C) per square meter ( $\mathrm{Li}$ et al., 2008b), summing up to roughly $2.5 \%$ of the global terrestrial carbon stocks (Wang et al., 2002). At Nam Co, the topsoils contain an almost $30 \mathrm{~cm}$ thick organic-rich layer (Wang et al., 2009b), thus representing considerable soil organic carbon (SOC) stocks. Due to higher plant productivity, alpine meadows in general represent a $\mathrm{CO}_{2}$ sink; however, the interannual and seasonal uptake is highly variable (Kato et al., 2004, 2006; Gu et al., 2003). Like plant productivity, the $\mathrm{CO}_{2}$ uptake depends on water availability and temperature, which exhibit diurnal, seasonal and annual fluctuations. The overall great importance of water availability and temperature on ecosystem-atmosphere $\mathrm{CO}_{2}$ exchange in the central Tibetan alpine Kobresia meadows was demonstrated in several studies through eddy covariance measurements (Zhang et al., 2018), chamber measurements (Zhang et al., 2018; Zhao et al., 2017), decomposition of cellulose cotton strips (Ohtsuka et al., 2008) and altitudinal transplantation experiments (Zhao et al., 2018). Similarly, carbon fluxes in alpine steppe biomes are driven by precipitation and temperature on a daily to seasonal and annual timescale. The interannual flux variability follows the varying monsoonal precipitation, showing a stronger tendency towards functioning as a $\mathrm{C}$ sink in wetter years and as a $\mathrm{C}$ source in drier years (Wang et al., 2018a; Zhu et al., 2015b). Soils that develop in the drier steppe areas tend to show lower organic carbon contents, therefore lowering the total $\mathrm{C}$ sink and source potential (Ohtsuka et al., 2008). Although the production of plant biomass may be hampered in steppes, the ecosystem may still act as a carbon sink through microbial $\mathrm{CO}_{2}$ fixing activities, as shown by a recent study on the TP that reported relatively high $\mathrm{CO}_{2}$ fixation capacity $\left(29 \mathrm{mg} \mathrm{kg}^{-1}\right.$ soil d ${ }^{-1}$, Zhao et al., 2018). Interestingly, this study also found that alpine steppe soils demonstrated significantly higher microbial $\mathrm{CO}_{2}$ fixation capacity compared to meadow soils ( $29 \mathrm{vs.}$ $18 \mathrm{mg} \mathrm{kg}^{-1}$ soil d $^{-1}$, respectively).

As a result of increasing precipitation and glacier runoff, wetlands in the Nam Co area are expanding, thus increasing emissions of $\mathrm{CH}_{4}$, which is 28 times more climate active than $\mathrm{CO}_{2}$ (IPCC, 2013). A study conducted in the alpine wetlands around Nam Co reported that $\mathrm{CH}_{4}$ emissions have increased exponentially with increasing precipitation, especially when soil moisture exceeded $80 \%$ (Wei et al., 2015). However, there was a large difference between swamp meadows and swamps (67 and $1444 \mu \mathrm{g} \mathrm{CH}_{4} \mathrm{~m}^{-2} \mathrm{~h}^{-1}$, respectively). Swamps are permanently inundated, while swamp meadows are usually seasonally inundated. Furthermore, SOC stocks are higher in swamps compared to swamp meadows (Wei et al., 2015). Large amounts of SOC in combination with anoxic conditions are the main precursors for methanogens activity, which results in increasing $\mathrm{CH}_{4}$ emissions to the atmosphere (Kato et al., 2013). Thus, the saturated soils with high SOC content produce higher $\mathrm{CH}_{4}$ emis- 


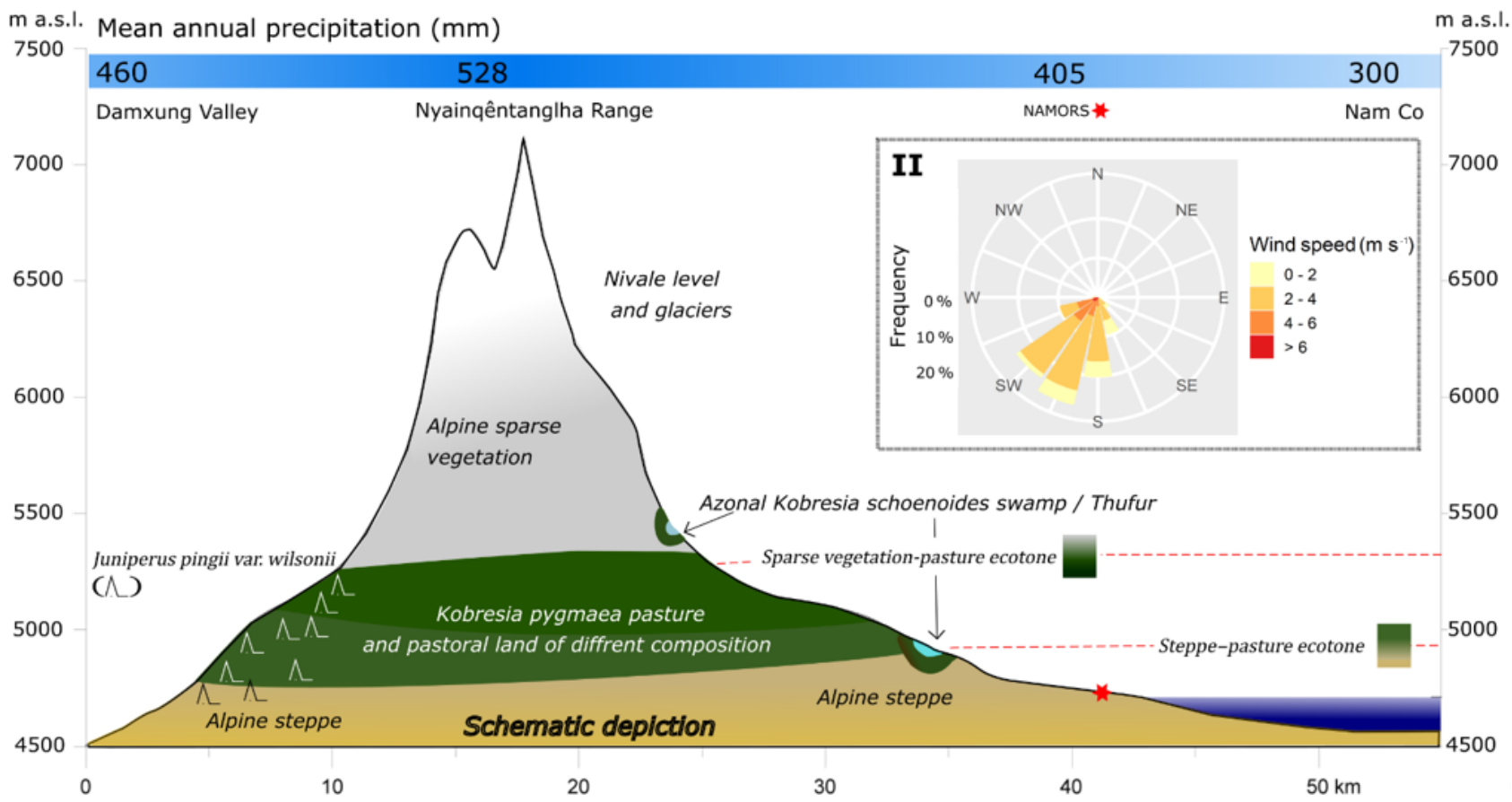

Figure 4. (I) Cross section from Damxung valley to the Nam Co study area (A'-A), as shown in Fig. 1b. Schematic depiction of altitudedependent biomes and azonal landforms; changes in chroma denote height-dependent biome shifts. Approximate biome heights were gained from satellite imagery (Sentinel-2B) and herewith-derived vegetation indices, field excursions, and the literature review (Ohtsuka et al., 2008; Wang and Yi, 2011). (II) Frequency, direction and velocity of mean daily wind measurements at the NAMORS $\left(30^{\circ} 46^{\prime} 22^{\prime \prime} \mathrm{N}, 90^{\circ} 57^{\prime} 47^{\prime \prime} \mathrm{E}\right)$ between 2005 and 2015.

sions (Deng et al., 2013). Observations from 2008 to 2013 at Nam Co have shown that alpine steppe and alpine meadows show annual uptake rates of 72 and $59 \mu \mathrm{C} \mathrm{CH}_{4} \mathrm{~m}^{-2} \mathrm{~h}^{-1}$, respectively (Wei et al., 2015); however, the corresponding emission rates are much higher. Generally, it is expected that the alpine wetland acts as a $\mathrm{CH}_{4}$ source, while the aerated soils of alpine steppe and alpine meadow act mainly as a $\mathrm{CH}_{4}$ sink.

As the grasslands on the TP are widely used for yak and sheep grazing, carbon cycling is influenced particularly through human activities and the degree of degradation. The intensity of grazing has a significant effect on $\mathrm{CO}_{2}$ fluxes, with moderate grazing enhancing belowground allocation of carbon (Hafner et al., 2012), while adversely affecting the $\mathrm{C}$-sink potential through reduction of aboveground and belowground biomass at higher grazing intensities (Babel et al., 2014). Overgrazing, along with the increase in burrowing pikas in the Tibetan grasslands, may increase nitrous oxide $\left(\mathrm{N}_{2} \mathrm{O}\right)$ emissions (Zhou et al., 2018), an important greenhouse gas with 297 times larger warming potential compared to $\mathrm{CO}_{2}$ (IPCC, 2013). Despite several studies focusing on greenhouse gas emissions on the TP, the magnitude of the $\mathrm{N}_{2} \mathrm{O}$ emissions in different ecosystems has not yet been estimated. Experimental studies on the eastern TP demonstrated that the rate of $\mathrm{N}_{2} \mathrm{O}$ emission may increase with increasing soil temperature and soil moisture under a future climate change scenario (Yan et al., 2018; Yingfang et al., 2018). Expanding wetland areas provide anoxic conditions for the release of methane and, due to the greater temperature sensitivity of permafrost areas, subsurface SOC is at high risk of loss, which may decrease the carbon sequestration potential in the region (Li et al., 2018). Besides carbon cycling through decomposition processes, responses to changing temperature and precipitation depend on the composition of decomposer communities (Glassman et al., 2018). Thus, the conclusive effects and feedback mechanisms (i.e., positive vs. negative loop) on warming are complex and not always clear.

\section{Paleoenvironments on the Tibetan Plateau and landscape evolution at Nam Co}

\subsection{Geodiversity and evolution of biodiversity}

Topography, geological context, climate and their complex interplay are key determinants for the distribution of organisms. In general, the ecoregion can serve as a proxy for community- and species-level biodiversity, which best describe communities of mammals, birds and plants (Smith et 
al., 2018). The TP forms a distinctive zoographical region, an "ecological island" (Deng et al., 2019), characterized by fauna that are adapted to high altitudes, drought, low temperatures and low oxygen levels (He et al., 2016). The TP forms unique high-altitude biogeographical biota by also harboring many unique lineages of other organisms, with a higher endemism of low dispersal species (Yang et al., 2009; Clewing et al., 2016). As mountain building has been directly associated with the development of biodiversity (Hoorn et al., 2013; Antonelli et al., 2018), the biodiversity hotspots are located in the south and southeast of the TP especially. There is also a pattern of increasing biodiversity from west to east, which correlates positively with increasing precipitation. In contrast, the harsh central areas of the TP show much lower richness but nevertheless harbor various endemics (Päckert et al., 2015). Throughout the geological formation of the TP, the mountainous southeastern parts have been hypothesized to serve as center of species diversification (Mosbrugger et al., 2018), although the core TP region is also suggested to represent a center of origin (Deng et al., 2011). The TP has been a source area for several mammalian lineages ("Out of Tibet hypothesis"; Deng et al., 2011), including the snow leopard and the arctic fox (Wang et al., 2015), as well as birds, such as redstarts (Voelker et al., 2015), and plants, such as Gentiana (Favre et al., 2015). These mountainous areas may also have acted as refugia, which preserved unique lineages over long periods (López-Pujol et al., 2011; Lei et al., 2014). Whether some endemic taxa represent relics of a formerly more diverse clade or have never extensively diversified remains unclear (Päckert et al., 2015). Besides being a center of origin, the TP may represent a center of accumulation as proposed by the examples of Saxifraga (Ebersbach et al., 2017), warblers (Johansson et al., 2007) and hynobiid salamander (Zhang et al., 2006). Overall, the regional biota of the TP is comprised mainly of Palearctic and Oriental species, Nearctic species from the Bering land bridge, as well as species from speciation in situ and postglacial recolonization from adjacent areas. The evolution of biodiversity on the TP has been affected by the combination of geological and climatic changes over the time of the uplift phases (Mosbrugger et al., 2018). Although many studies have associated recent in situ radiations to different uplift phases of the TP, Renner (2016) pointed out that the evidence for recent rapid uplift (9-8 or 3.6-2.6 Ma) remains doubtful and controversial. As proposed by the "mountain geobiodiversity" hypothesis, the evolution of biodiversity on the TP is a result of an increasing local geodiversity in combination with rapid climatic oscillations and steep ecological gradients (Mosbrugger et al., 2018).

The combination of geological, climatic and ecological changes has left its footprint in the history of Nam Co. There are at least seven different levels of continuous terraces around $\mathrm{Nam} \mathrm{Co}$, with the highest being over 30 meters above the current lake level, corresponding well with the elevation of the natural spillway in the northeast of Nam Co.
Several authors claim the existence of a much larger fluvial lake system called Old Qiangtang Lake, which covered an area of around $30000-50000 \mathrm{~km}^{2}$ or more (Li et al., 1981; Zhu et al., 2002). The connections provided by a large lake allowed gene flow between drainages, which is reflected, for example, by the closely related clades of schizothoracine fish (Cyprinidae, Osteichthyes) from Nam Co and the surrounding lakes, compared with more distant parts of the TP (He et al., 2016). In contrast, due to a vector-mediated passive dispersal across large areas, other aquatic taxa, such as freshwater snails, seem to have been less influenced by drainage histories (Oheimb et al., 2011). Higher lake terraces are older, suggesting a long-term reduction in lake level (Zhu et al., 2002). This may be associated with an evolution from wet to dry phase, which Li et al. (1981) connects to the gradual uplift of the plateau from early Pleistocene to the Holocene. However, there is an alternative suggestion to this interpretation of a rather modern uplift proposed by Renner (2016) who states that large parts of the TP had already reached average heights of $4000 \mathrm{~m}$ and more during the mid-Eocene ( $\sim 40 \mathrm{Ma}$ ago). Recent findings of palm leave fossils on the central part of the TP, dated to ca. $25.5 \pm 0.5$ million years, do not suggest a presence of such a high plateau before the Neogene (Su et al., 2019). Thus, although it is suggested that the final large lake phase took place ca. 40-25 ka cal BP (Lehmkuhl et al., 2002; Zhu et al., 2002), the complex relationship between evolution of the TP and the development and the temporal existence of Old Qiangtang Lake are not completely resolved.

\subsection{Holocene lake level changes and climate reconstruction based on aquatic bioindicators}

Lake sediments contain important indicators or proxies that can be used to reconstruct limnological and (hydro-) climatic conditions over long time periods (Zhu et al., 2010a; Wrozyna et al., 2010). Widely used environmental indicators include communities of diatoms (Bacillariophyceae) and ostracods (Crustacea) as they are abundant and usually preserve well in sediments (Kasper et al., 2013). For example, the investigations of Quaternary ostracods, modern assemblages, and stable isotopes from Nam Co and nearby water bodies represent the most detailed application of ostracod analysis in the south-central region of the TP (Mischke, 2012). Different approaches (stratigraphy, paleoecology, etc.) detected several climatic fluctuations between warmer-cooler and wetter-drier periods (Fig. 5). In general, higher lake levels based on aquatic fauna suggest a more humid environment during the early and middle Holocene, which displayed a shift pattern compared to the northern TP (Wünnemann et al., 2018). Together with the indicator species approach and the application of transfer functions for Nam Co sediments, different stages can be recognized. In Stage I (8.4$6.8 \mathrm{ka}$ cal BP), the climate changed from warm humid to cold arid with water depth being much lower than today (Zhu 
et al., 2010a). In Stage II (6.8-2.9 ka cal BP), environmental conditions returned to warm and humid (Zhu et al., 2010a). During 4-2 kacalBP, lake water depth initially remained much shallower than today but then gradually increased due to high rates of precipitation (Frenzel et al., 2010). The presence of the diatom taxa Stephanodiscus in this stage indicates stronger monsoon activity and higher availability of nutrients (Kasper et al., 2013). Finally, in stage III (2.9 ka cal BP to present), the climate again became warm humid, with a cold dry event between 1.7 and $1.5 \mathrm{kacal} \mathrm{BP}$ (Zhu et al., 2010a). Between 2 and $1.2 \mathrm{kacal} \mathrm{BP}$, benthic diatoms inferred a lower water level and drier climate (Kasper et al., 2013). Subsequently, wetter conditions and an increase in lake level was detected (1.2 ka cal BP until $250 \mathrm{cal} \mathrm{BP})$, possibly corresponding to the Medieval Warm Period (MWP), with high planktonic diatom species and high ostracod diversity (Kasper et al., 2013). During the late Holocene, the minimum water level occurred throughout the Little Ice Age (LIA) ( 1490 and 1760 CE) (Frenzel et al., 2010). However, the lake level increased towards the present, which is plausibly linked to the melting of the glacier due to the current warming.

Although a large number of studies describe profound hydrological changes and general climate fluctuations, there are several uncertainties regarding taxonomy, resolution and proxy sensitivities. For example, modern ostracod data detects several morphological variations, characterized by different nodding or shell sizes, which could lead to an erroneous ecological interpretation and later, vague paleoenvironmental conclusions in relation to salinity changes (Fürstenberg et al., 2015). In paleo-studies, different sedimentation rates and uncertainties in the core chronologies also cause a lack of correspondence between signals detected by different proxies (Wang et al., 2012). For this reason, it is surrogate to understand the precise causal relationships between a complex environmental gradient (e.g., water depth, water chemistry, temperature, etc.) and the response of bioindicators. Although ecological information is still poorly known for many species, ostracod and diatom assemblages represent reliable proxies to trace the climatic history of Nam Co.

Further emphasis should be placed on combining morphology and DNA analysis to corroborate the classification of the species already described. Furthermore, experiments with living individuals should be performed under controlled environmental variables to allow the setup of a transfer function that could be used to evaluate quantitative data for paleoreconstructions.

\subsection{Holocene vegetation cover and climate reconstruction based on pollen records}

The comparison of modern pollen assemblages with those from sediment cores allows the reconstruction of floristic diversity and distribution across various timescales. Vegeta- tion patterns contribute to the reconstruction of past climate and the assessment of the degree of local human influence. Modern vegetation belts around Nam Co reveal that alpine steppes contain mostly species of Artemisia (Asteraceae) and Poaceae, while alpine meadows and swamps are dominated by Cyperaceae ( $\mathrm{Li}$ et al., 2011). The sedimentary pollen ratio of Artemisia to Cyperaceae (A/Cy) can, within certain limitations, be used to reconstruct past climates ( $\mathrm{Li}$ et al., 2011; Li, 2018; Zhu et al., 2015a) provided that vegetation belts move with altitude during climate change. For example, when the climate is warmer and drier, alpine steppe reaches higher up the mountain, displacing alpine meadow into areas further away from the lake, leading to a higher input of Artemisia pollen into the nearby lake and consequently a higher A/Cy pollen ratio in the sediments. However, the $\mathrm{A} / \mathrm{Cy}$ pollen ratio and abundance of tree pollen originating from a short distance can be altered by human-driven change of plant composition, hence the beginning of pastoral economy might limit the explanatory power of pollen records (Adamczyk, 2010; Miehe et al., 2014). Pollen composition inferred from sediment cores reveals a downward shift of the altitudinal vegetation belts since $8.4 \mathrm{ka} \mathrm{BP}$ ( $\mathrm{Li}$ et al., 2011). A major extension of alpine pasture and alpine sparse vegetation closer to the lake shore during the late Holocene is corroborated by a pollen-based climate reconstruction from a peat core near Nam Co (Herrmann et al., 2010) and two other pollen records from the eastern lake shore (Adamczyk, 2010). They found a trend of increasing temperatures from the late glacial until the early Holocene, accompanied by an extension of alpine steppe, tree and shrub vegetation. Already in this period, synanthrope taxa pollen are increasing in the data used by Adamczyk (2010) with the only small occurrence of, for example, Plantago lanceolata in the whole profile. This very early signal shows that a lot of room still exists for studies of pollen archives around Nam Co, with much doubt still persisting at present. Climate fluctuated between dry and humid from 8.5 to $4.8 \mathrm{ka} \mathrm{BP}$, with an intense cold regression between 8.1 to $7.8 \mathrm{ka} \mathrm{BP}$. The onset of human activity at Nam Co is dated to $5.6 \mathrm{ka} \mathrm{BP}$ according to synanthrope taxa proxies (Li et al., 2011; Herrmann et al., 2010). Between 4.8 and $0.7 \mathrm{kaBP}$, a relatively stable climate with predominantly humid conditions developed (Fig. 5), and the vegetation pattern already showed trends of a human-made steppe biome, potentially a plagioclimax (Adamczyk, 2010). Since $0.7 \mathrm{ka} \mathrm{BP}$, drier conditions prevailed.

Whether and to what extent the central Tibetan Plateau was forested and what caused the forest decline are the subject of ongoing discussion (Miehe et al., 2006, 2019). This matter is closely related to the prior discussed onset of more intense human activity in the area, since parts of the discussion involve a human-made forest clearing in combination with a natural forest decline. As stated, there are only occurrences of shrubs (Juniperus pingii var. wilsonii and Salix, Nölling, 2006) in the Nam Co area. No remains and no reliable evidence of a once tree-rich vegetation have yet been 


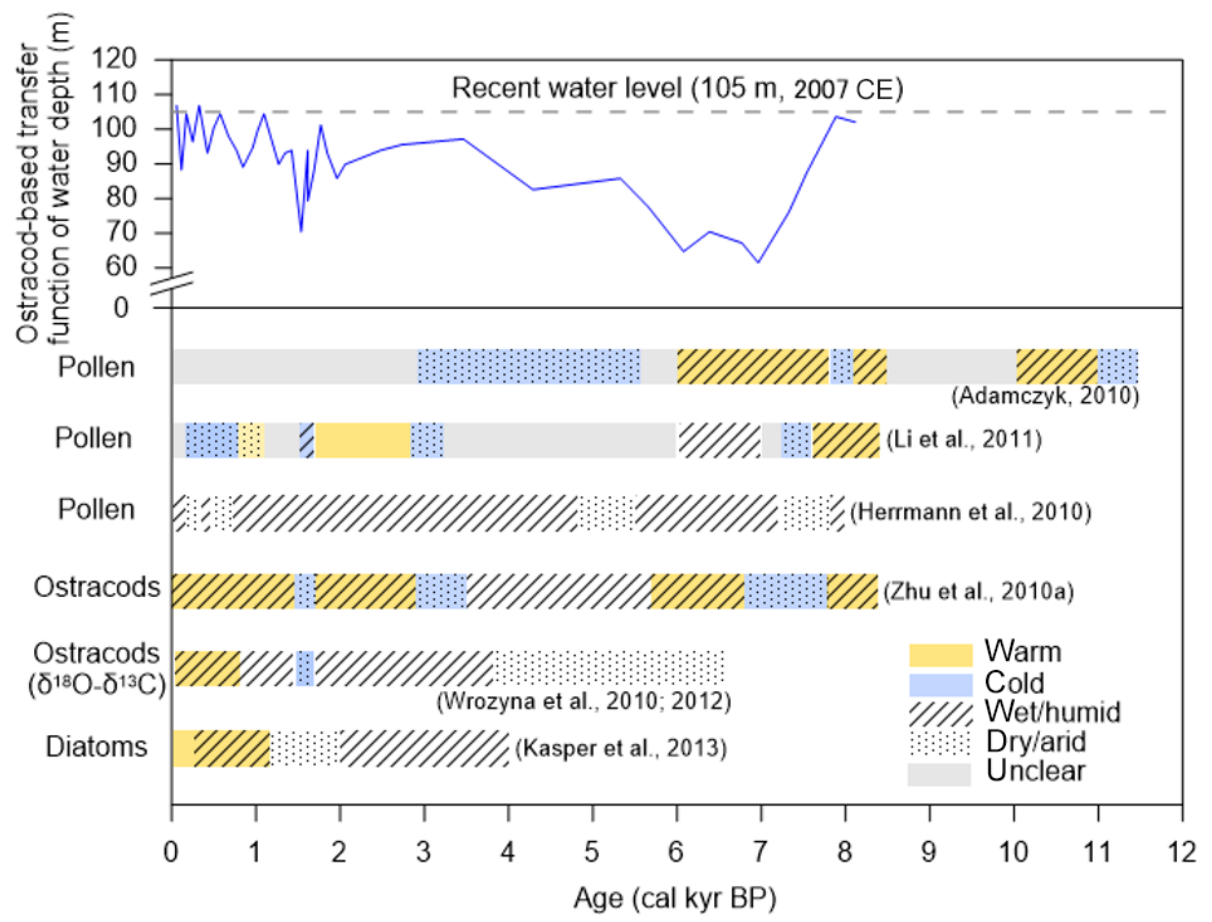

Figure 5. Comparisons of the reconstructed climate conditions based on fossils of pollen (Li et al., 2011; Adamczyk, 2010; Herrmann et al., 2010), ostracods (Zhu et al., 2010a), Ostracod $\delta^{18}$ O (Wrozyna et al., 2010, 2012) and diatoms (Kasper et al., 2013) from sediment cores in, and at the shoreline of, Nam Co. Ostracod-based water depth transfer function (Zhu et al., 2010a) (blue line) was used to indicate long-term hydrological changes and all reconstructed water depth values were adjusted to the maximum water level of the lake according to the $45 \mathrm{~m}$ difference between this study site $(60 \mathrm{~m})$ and the deepest site $(105 \mathrm{~m})$ at Nam Co. The main species are also shown in different periods.

found in the Nam Co catchment. According to locals, there exist several caves with potentially (pre)historic tree depictions of unknown age. Unfortunately, there is no verification of their existence nor any dating approach. Since the area of Damxung still does feature larger occurrences of Juniperus pingii var. wilsonii and, around $4250 \mathrm{~m}$ a.s.1., tree stands of Juniperus tibetica in enclosed areas, there is the potential to discuss that these species have been more numerous in this area in the past (i.e., last tooth theory). Miehe et al. (2019) show locations of forest relicts and give a drought line of 200-250 mm precipitation and elevations between 3600 and $4000 \mathrm{~m}$ a.s.l. as the upper tree line. Questions arise as to whether there has been an expansion of J. tibetica into the Nam Co catchment in earlier times, which would be feasible within certain limitations according to the presented thresholds. Charred micro remains as a potential sign of fire-driven forest decline are missing in one of the profiles of Adamczyk (2010) but can be found throughout the Holocene until 1 ka cal BP (Herrmann et al., 2010). The authors attribute the size and shape of the charcoal remains to local, small-scale burning of wood and leaves, not showing signs of larger forest clearings. In addition to the burning of Juniperus trees for religious reasons (Miehe et al., 2006), trees and shrubs may have been burned for heating or clearing of pastures by nomads. Following the presumptuous argumentation of some authors, the trees were previously able to spread again due to sufficient precipitation provided by the summer monsoon. Furthermore, the occurrence of synanthropic taxa has been observed in the nearby Damxung valley since $8.5 \mathrm{ka}$ cal BP, corroborating the strong anthropogenic influence on the formation and restructuring of the vegetation patterns in the area (Schlütz et al., 2007). The decrease in summer precipitation and temperature, in conjunction with ongoing human activity, ultimately led to the total disappearance of trees and the formation of the alpine grasslands and steppe as we know them today (see Sect. 2.4). Furthermore, the occurrence of synanthropic taxa has been observed in the nearby Damxung valley since $8.5 \mathrm{ka}$ cal BP (Schlütz et al., 2007). This corroborates the strong anthropogenic influence on the formation and restructuring of vegetation patterns in the area but leaves a time gap of almost $3 \mathrm{ka}$ between the evidence from Damxung valley and Nam Co. Hence, further research is needed to address the question of onset of human activity and degree of landscape modification.

\section{Conclusions and perspectives}

This literature review summarizes the manifold environmental changes affecting abiotic and biotic processes in the area caused by past and ongoing climate change. Ecosystems on 
the Tibetan Plateau experience an increase in air temperature roughly twice the global average. This has accelerated deglaciation of the Nyainqêntanglha range during the last few decades, leading to substantial inflow of freshwater and various solutes resulting from weathering to the lake. The combined effects of overgrazing by livestock and warmingaccelerated degradation processes of the alpine grasslands further increase surface runoff in the catchment. Moreover, warmer and wetter climate, as well as pasture degradation, may turn alpine wetlands and steppe pasture ecosystems into an overall source of methane and carbon dioxide, respectively. Based on the reviewed literature focusing on the catchment of Nam Co, we outline perspectives to improve the understanding of the close connections between geodiversity and biodiversity. (1) Permafrost areas act as buffers of the water budget and influence the behavior of geomorphological processes and periglacial landforms. Although a significant warming and consequent decay of permafrost have been reported throughout the TP in recent decades, studies on permafrost in the Nam Co catchment and in the immediate Nyainqêntanglha range are missing. (2) The rising lake level trend, starting in late 1970, had a point of reflection around 2009, which indicates changes of variable precipitation and evaporation trends, reduced water inflow from already melted glaciers, and additional ground water seepage out of the lake. Therefore, long-term monitoring is necessary to calibrate and validate models properly and to achieve a more accurate climate prognosis. (3) To improve climate modeling approaches, the dynamics of DOM, $\mathrm{CO}_{2}$ and $\mathrm{CH}_{4}$ fluxes need further clarification by in-depth analysis of the different biomes and in situ observations. (4) The development of molecular methods for biomonitoring and water quality assessment has advanced greatly during the last decade with the aim of providing clear monitoring standards. These offer time- and cost-effective approaches for complementary studies to tackle community shifts of various water quality indicator organisms. (5) Alongside the "traditional" paleo-bioindicator analysis, DNA-based taxa identification methods hold also a great potential for application in paleoecological studies to provide improved taxa differentiating accuracy. Various biological and geochemical proxies in Nam Co sediments have enabled the tracking of historical events and the reconstruction of past environments, which provide information about the magnitudes and directions of past climate change and thus a key to assess future changes. Both the formation of high-elevation environments and pronounced past climate oscillations have contributed to the development of biota on the TP. Interdisciplinary research of the Nam Co catchment has provided vast insights into how warming trends may affect ecosystems from microbes to the top of the food chain. Recognizing the impacts of a warming climate is the base for establishing effective climate change adaptation strategies and actions in the TP region and in alpine regions in general.
Data availability. As this paper is reviewing existing literature findings, there were no data analyzed that are not already published in the studies we cite. The dataset from which Table 1 was generated was provided by the Institute of Tibetan Plateau Research and is publicly available under https://data.tpdc.ac. cn/en/data/4deeb2b4-4fc1-4c7c-b0c6-6263a547d53f/, last access: 4 March 2020 (Wang and $\mathrm{Wu}, 2018$ ) and https://data.tpdc.ac. cn/en/data/3767cacc-96e3-48b2-b66c-dac92800ca69/, last access: 4 March 2020 (Wang, 2019).

Author contributions. SA, MAR, JB, PEG, JK, WK, LK, PM, FN, ER, HT, TVT and YW contributed equally to the content of the paper. AS conceived the idea and was responsible for funding acquisition. SA, JB, PM and FN structured the main text body. The following authors were in charge of the corresponding sections: JB, ER, TVT - "Glacier retreat and hydrological patterns of Nam Co"; PEG, LK - "Enhanced water availability controls changes in lake water chemistry"; PM, FN - "Vegetation, soils and pasture degradation in the catchment", "Effects on carbon cycling in alpine ecosystems", and "Holocene vegetation cover and climate reconstruction based on pollen records"; SA, PEG, WK - "Geodiversity and evolution of biodiversity" and "Paleo-lake level changes and climate reconstruction". The tables and figures were prepared as follows: ER - Fig. 1; JB and FN - Tables 1 and 2 and Figs. 2 and 3; PM - Fig. 4; WK Fig. 5.

Competing interests. The authors declare that they have no conflict of interest.

Acknowledgements. We thank all colleagues who contributed to this review. We especially thank Miguel Vences and Bernd Wünnemann for their enriching comments that greatly improved the manuscript. We also thank Binbin Wang for providing precipitation data. The authors are very grateful to Georg Miehe and one other anonymous reviewer for their helpful comments that greatly helped to improve the review. This research is a contribution to the International Research Training Group (GRK 2309/1) "Geo-ecosystems in transition on the Tibetan Plateau (TransTiP)" funded by Deutsche Forschungsgemeinschaft (DFG).

Financial support. This research is a contribution to the International Research Training Group (GRK 2309/1) "Geoecosystems in transition on the Tibetan Plateau (TransTiP)" funded by Deutsche Forschungsgemeinschaft (DFG).

Review statement. This paper was edited by Kirsten Thonicke and reviewed by Georg Miehe and one anonymous referee.

\section{References}

Adamczyk, S.: Vegetationsgeschichtliche Untersuchung zur Geschichte des menschlichen Eingriffs in den Haushalt der 
Natur Ost-, Zentral-Tibets und West-Sichuans, sowie zum Problem der eiszeitlichen Waldrefugien, Dissertation, Institut für Botanik, Universität Hohenheim, Hohenheim, 2010.

Antonelli, A., Kissling, W. D., Flantua, S. G. A., Bermúdez, M. A., Mulch, A., Muellner-Riehl, A. N., Kreft, H., Linder, H. P., Badgley, C., Fjeldså, J., Fritz, S. A., Rahbek, C., Herman, F., Hooghiemstra, H., and Hoorn, C.: Geological and climatic influences on mountain biodiversity, Nat. Geosci., 11, 718-725, https://doi.org/10.1038/s41561-018-0236-z, 2018.

Babel, W., Biermann, T., Coners, H., Falge, E., Seeber, E., Ingrisch, J., Schleuß, P.-M., Gerken, T., Leonbacher, J., Leipold, T., Willinghöfer, S., Schützenmeister, K., Shibistova, O., Becker, L., Hafner, S., Spielvogel, S., Li, X., Xu, X., Sun, Y., Zhang, L., Yang, Y., Ma, Y., Wesche, K., Graf, H., Leuschner, C., Guggenberger, G., Kuzyakov, Y., Miehe, G., and Foken, T.: Pasture degradation modifies the water and carbon cycles of the Tibetan highlands, Biogeosciences, 11, 6633-6656, https://doi.org/10.5194/bg-11-6633-2014, 2014.

Bellard, C., Bertelsmeier, C., Leadley, P., Thuiller, W., and Courchamp, F.: Impacts of climate change on the future of biodiversity, Ecol. Lett., 15, 365-377, https://doi.org/10.1111/j.14610248.2011.01736.x, 2012.

Bolch, T., Yao, T., Kang, S., Buchroithner, M. F., Scherer, D., Maussion, F., Huintjes, E., and Schneider, C.: A glacier inventory for the western Nyainqentanglha Range and the Nam Co Basin, Tibet, and glacier changes 1976-2009, The Cryosphere, 4, 419433, https://doi.org/10.5194/tc-4-419-2010, 2010.

Callieri, C., Hernández-Avilés, S., Salcher, M. M., Fontaneto, D., and Bertoni, R.: Distribution patterns and environmental correlates of Thaumarchaeota abundance in six deep subalpine lakes, Aquat. Sci., 78, 215-225, https://doi.org/10.1007/s00027-0150418-3, 2016.

Cao, J., Adamowski, J. F., Deo, R. C., Xu, X., Gong, Y., and Feng, Q.: Grassland Degradation on the Qinghai-Tibetan Plateau: Reevaluation of Causative Factors, Rangeland Ecol. Manag., 72, 988-995, https://doi.org/10.1016/j.rama.2019.06.001, 2019.

Chen, I.-C., Hill, J. K., Ohlemüller, R., Roy, D. B., and Thomas, C. D.: Rapid range shifts of species associated with high levels of climate warming, Science, 333, 1024-1026, https://doi.org/10.1126/science.1206432, 2011.

Cheng, G. and Wu, T.: Responses of permafrost to climate change and their environmental significance, Qinghai-Tibet Plateau, J. Geophys. Res., 112, 169, https://doi.org/10.1029/2006JF000631, 2007.

Chesworth, W., Camps Arbestain, M., Macías, F., Spaargaren, O., Mualem, Y., Morel-Seytoux, H. J., Horwath, W. R., Almendros, G., Grossl, P. R., Sparks, D. L., Fairbridge, R. W., Singer, A., Eswaran, H., and Micheli, E.: Classification of Soils: World Reference Base (WRB) for soil resources, in: Encyclopedia of Soil Science, edited by: Chesworth, W., Encyclopedia of Earth Sciences Series, Springer, Dordrecht, 120-122, 2008.

Clewing, C., Albrecht, C., and Wilke, T.: A Complex System of Glacial Sub-Refugia Drives Endemic Freshwater Biodiversity on the Tibetan Plateau, PloS One, 11, e0160286, https://doi.org/10.1371/journal.pone.0160286, 2016.

Cuo, L. and Zhang, Y.: Spatial patterns of wet season precipitation vertical gradients on the Tibetan Plateau and the surroundings, Sci. Rep., 7, 5057, https://doi.org/10.1038/s41598-017-05345-6, 2017.
Deng, T., Wang, X., Fortelius, M., Li, Q., Wang, Y., Tseng, Z. J., Takeuchi, G. T., Saylor, J. E., Säilä, L. K., and Xie, G.: Out of Tibet: Pliocene woolly rhino suggests high-plateau origin of Ice Age megaherbivores, Science, 333, 1285-1288, https://doi.org/10.1126/science.1206594, 2011.

Deng, T., Wu, F., Zhou, Z., and Su, T.: Tibetan Plateau: An evolutionary junction for the history of modern biodiversity, Sci. China Earth Sci., 63, 172-187, https://doi.org/10.1007/s11430019-9507-5, 2019.

Deng, Y., Cui, X., Lüke, C., and Dumont, M. G.: Aerobic methanotroph diversity in Riganqiao peatlands on the Qinghai-Tibetan Plateau, Environ. Microbiol. Rep., 5, 566-574, https://doi.org/10.1111/1758-2229.12046, 2013.

Dong, S., Peng, F., You, Q., Guo, J., and Xue, X.: Lake dynamics and its relationship to climate change on the Tibetan Plateau over the last four decades, Reg. Environ. Change, 18, 477-487, https://doi.org/10.1007/s10113-017-1211-8, 2018.

Dorji, T., Hopping, K. A., Wang, S., Piao, S., Tarchen, T., and Klein, J. A.: Grazing and spring snow counteract the effects of warming on an alpine plant community in Tibet through effects on the dominant species, Agr. Forest Meteorol., 263, 188-197, https://doi.org/10.1016/j.agrformet.2018.08.017, 2018.

Dorji, T., Moe, S. R., Klein, J. A., and Totland, Ø.: Plant Species Richness, Evenness, and Composition along Environmental Gradients in an Alpine Meadow Grazing Ecosystem in Central Tibet, China, Arctic, Antarctic Alpine Res., 46, 308-326, https://doi.org/10.1657/1938-4246-46.2.308, 2014.

Dorji, T., Totland, O., Moe, S. R., Hopping, K. A., Pan, J., and Klein, J. A.: Plant functional traits mediate reproductive phenology and success in response to experimental warming and snow addition in Tibet, Glob. Change Biol., 19, 459-472, https://doi.org/10.1111/gcb.12059, 2013.

Du, Y., Huang, Z., Xie, M., Farooq, A., and Chen, C.: Temporal Variations in the Quantity of Groundwater Flow in Nam Co Lake, Water, 10, 941, https://doi.org/10.3390/w10070941, 2018.

Ebersbach, J., Schnitzler, J., Favre, A., and Muellner-Riehl, A. N.: Evolutionary radiations in the species-rich mountain genus Saxifraga L, BMC Evol. Biol., 17, 119, https://doi.org/10.1186/s12862-017-0967-2, 2017.

Favre, A., Päckert, M., Pauls, S. U., Jähnig, S. C., Uhl, D., Michalak, I., and Muellner-Riehl, A. N.: The role of the uplift of the Qinghai-Tibetan Plateau for the evolution of Tibetan biotas, Biol. Rev. Camb. Philos., 90, 236-253, https://doi.org/10.1111/brv.12107, 2015.

Frauenfelder, R. and Kääb, A. (Eds.): Glacier mapping from multitemporal optical remote sensing data within the Brahmaputra river basin: Proceedings of the 33rd International Symposium on Remote Sensing of Environment, 4-8, 2009.

Frenzel, P., Wrozyna, C., Xie, M., Zhu, L., and Schwalb, A.: Palaeowater depth estimation for a 600-year record from Nam Co (Tibet) using an ostracod-based transfer function, Quaternary Int., 218, 157-165, https://doi.org/10.1016/j.quaint.2009.06.010, 2010.

Fürstenberg, S., Frenzel, P., Peng, P., Henkel, K., and Wrozyna, C.: Phenotypical variation in Leucocytherella sinensis Huang, 1982 (Ostracoda): a new proxy for palaeosalinity in Tibetan lakes, Hydrobiologia, 751, 55-72, https://doi.org/10.1007/s10750-0142171-3, 2015. 
Ganjurjav, H., Gao, Q., Gornish, E. S., Schwartz, M. W., Liang, Y., Cao, X., Zhang, W., Zhang, Y., Li, W., Wan, Y., Li, Y., Danjiu, L., Guo, H., and Lin, E.: Differential response of alpine steppe and alpine meadow to climate warming in the central Qinghai-Tibetan Plateau, Agr. Forest Meteorol., 223, 233-240, https://doi.org/10.1016/j.agrformet.2016.03.017, 2016.

Glassman, S. I., Weihe, C., Li, J., Albright, M. B. N., Looby, C. I., Martiny, A. C., Treseder, K. K., Allison, S. D., and Martiny, J. B. H.: Decomposition responses to climate depend on microbial community composition, P. Natl. Acad. Sci. USA, 115, 1199411999, https://doi.org/10.1073/pnas.1811269115, 2018.

Gu, S., Tang, Y., Du, M., Kato, T., Li, Y., Cui, X., and Zhao, X.: Short-term variation of $\mathrm{CO}_{2}$ flux in relation to environmental controls in an alpine meadow on the Qinghai-Tibetan Plateau, J. Geophys. Res., 108, 711, https://doi.org/10.1029/2003JD003584, 2003.

Hafner, S., Unteregelsbacher, S., Seeber, E., Lena, B., Xu, X., Li, X., Guggenberger, G., Miehe, G., and Kuzyakov, Y.: Effect of grazing on carbon stocks and assimilate partitioning in a Tibetan montane pasture revealed by ${ }^{13} \mathrm{CO}_{2}$ pulse labeling, Glob. Change Biol., 18, 528-538, https://doi.org/10.1111/j.13652486.2011.02557.x, 2012.

Harris, R. B.: Rangeland degradation on the QinghaiTibetan plateau: A review of the evidence of its magnitude and causes, J. Arid Environ., 74, 1-12, https://doi.org/10.1016/j.jaridenv.2009.06.014, 2010.

He, D., Chen, Y., Liu, C., Tao, J., Ding, C., and Chen, Y.: Comparative phylogeography and evolutionary history of schizothoracine fishes in the Changtang Plateau and their implications for the lake level and Pleistocene climate fluctuations, Ecol. Evol., 6, 656-674, 2016.

Herber, J., Klotz, F., Frommeyer, B., Weis, S., Straile, D., Kolar, A., Sikorski, J., Egert, M., Dannenmann, M., and Pester, M.: A single Thaumarchaeon drives nitrification in deep oligotrophic Lake Constance, Environmental microbiology, 22, 212228, https://doi.org/10.1111/1462-2920.14840, 2020.

Herrmann, M., Lu, X., Berking, J., Schütt, B., Yao, T., and Mosbrugger, V.: Reconstructing Holocene vegetation and climate history of Nam Co area (Tibet), using pollen and other palynomorphs, Quaternary Int., 218, 45-57, https://doi.org/10.1016/j.quaint.2009.05.007, 2010.

Hoorn, C., Mosbrugger, V., Mulch, A., and Antonelli, A.: Biodiversity from mountain building, Nat. Geosci., 6, https://doi.org/10.1038/ngeo1742, 2013.

Hopping, K. A., Yangzong, C., and Klein, J. A.: Local knowledge production, transmission, and the importance of village leaders in a network of Tibetan pastoralists coping with environmental change, Ecol. Soc., 21, 25, https://doi.org/10.5751/ES-08009210125, 2016.

Hu, A., Yao, T., Jiao, N., Liu, Y., Yang, Z. A. O., and Liu, X.: Community structures of ammonia-oxidising archaea and bacteria in high-altitude lakes on the Tibetan Plateau, Freshwater Biol., 55, 2375-2390, 2010.

Huang, S., Liu, Y., Hu, A., Liu, X., Chen, F., Yao, T., and Jiao, N.: Genetic diversity of picocyanobacteria in Tibetan lakes: Assessing the endemic and universal distributions, Appl. Environ. Microbiol., 80, 7640-7650, https://doi.org/10.1128/AEM.0261114, 2014.
IPCC: Climate change 2013: The physical science basis; Working Group I contribution to the fifth assessment report of the Intergovernmental Panel on Climate Change, edited by: Stocker, T. F., Qin, D., Plattner, G.-K., Tignor, M., Allen, S. K., Boschung, J., Nauels, A., Xia, Y., Bex, V., and Midgley, P. M., Elektronische Ressource, Cambridge University Press, Cambridge, United Kingdom and New York, NY, USA, 1535 pp., 2013.

Jarvis, A., Reuter, H., Nelson, A., and Guevara, E.: Hole-filled seamless SRTM data v4, International Centre for Tropical Agriculture (CIAT), 2008.

Ji, Q., Yang, T.-b., Dong, J., and He, Y.: Glacier variations in response to climate change in the eastern Nyainqêntanglha Range, Tibetan Plateau from 1999 to 2015, Arctic, Antarctic Alpine Res., 50, e1435844, https://doi.org/10.1080/15230430.2018.1435844, 2018.

Jiang, L., Nielsen, K., Andersen, O. B., and Bauer-Gottwein, P.: Monitoring recent lake level variations on the Tibetan Plateau using CryoSat-2 SARIn mode data, J. Hydrol., 544, 109-124, https://doi.org/10.1016/j.jhydrol.2016.11.024, 2017.

Johansson, U. S., Alström, P., Olsson, U., Ericson, P. G. P., Sundberg, P., and Price, T. D.: Build-up of the Himalayan avifauna through immigration: a biogeographical analysis of the Phylloscopus and Seicercus warblers, Evolution, 61, 324-333, 2007.

Kaiser, K. and Kalbitz, K.: Cycling downwards - dissolved organic matter in soils, Soil Biol. Biochem., 52, 29-32, https://doi.org/10.1016/j.soilbio.2012.04.002, 2012.

Kaiser, K., Miehe, G., Barthelmes, A., Ehrmann, O., Scharf, A., Schult, M., Schlütz, F., Adamczyk, S., and Frenzel, B.: Turf-bearing topsoils on the central Tibetan Plateau, China: Pedology, botany, geochronology, CATENA, 73, 300-311, https://doi.org/10.1016/j.catena.2007.12.001, 2008.

Kasper, T., Frenzel, P., Haberzettl, T., Schwarz, A., Daut, G., Meschner, S., Wang, J., Zhu, L., and Mäusbacher, R.: Interplay between redox conditions and hydrological changes in sediments from Lake Nam Co (Tibetan Plateau) during the past 4000 cal BP inferred from geochemical and micropaleontological analyses, Palaeogeogr. Palaeocl., 392, 261-271, https://doi.org/10.1016/j.palaeo.2013.09.027, 2013.

Kato, T., Tang, Y., Gu, S., Hirota, M., Du, M., Li, Y., and Zhao, X.: Temperature and biomass influences on interannual changes in $\mathrm{CO}_{2}$ exchange in an alpine meadow on the Qinghai-Tibetan Plateau, Glob. Change Biol., 12, 1285-1298, https://doi.org/10.1111/j.1365-2486.2006.01153.x, 2006.

Kato, T., Tang, Y., Song, G., Hirota, M., Cui, X., Du, M., Li, Y., Zhao, X., and Oikawa, T.: Seasonal patterns of gross primary production and ecosystem respiration in an alpine meadow ecosystem on the Qinghai-Tibetan Plateau, J. Geophys. Res., 109, 711, https://doi.org/10.1029/2003JD003951, 2004.

Kato, T., Yamada, K., Tang, Y., Yoshida, N., and Wada, E.: Stable carbon isotopic evidence of methane consumption and production in three alpine ecosystems on the Qinghai-Tibetan Plateau, Atmos. Environ., 77, 338-347, https://doi.org/10.1016/j.atmosenv.2013.05.010, 2013.

Keil, A., Berking, J., Mügler, I., Schütt, B., Schwalb, A., and Steeb, P.: Hydrological and geomorphological basin and catchment characteristics of Lake Nam Co, South-Central Tibet, Quaternary Int., 218, 118-130, https://doi.org/10.1016/j.quaint.2009.02.022, 2010 . 
Klein, J. A., Harte, J., and Zhao, X.-Q.: Experimental warming causes large and rapid species loss, dampened by simulated grazing, on the Tibetan Plateau, Ecol. Lett., 7, 1170-1179, https://doi.org/10.1111/j.1461-0248.2004.00677.x, 2004.

Klein, J. A., Harte, J., and Zhao, X.-Q.: Decline in Medicinal and Forage Species with Warming is Mediated by Plant Traits on the Tibetan Plateau, Ecosystems, 11, 775-789, https://doi.org/10.1007/s10021-008-9160-1, 2008.

Kong, P., Na, C., Brown, R., Fabel, D., Freeman, S., Xiao, W., and Wang, Y.: Cosmogenic ${ }^{10} \mathrm{Be}$ and ${ }^{26} \mathrm{Al}$ dating of paleolake shorelines in Tibet, J. Asian Earth Sci., 41, 263-273, https://doi.org/10.1016/j.jseaes.2011.02.016, 2011.

Lami, A., Turner, S., Musazzi, S., Gerli, S., Guilizzoni, P., Rose, N. L., Yang, H., Wu, G., and Yang, R.: Sedimentary evidence for recent increases in production in Tibetan plateau lakes, Hydrobiologia, 648, 175-187, https://doi.org/10.1007/s10750-010-02632, 2010 .

Lazhu, Yang, K., Wang, J., Lei, Y., Chen, Y., Zhu, L., Ding, B., and Qin, J.: Quantifying evaporation and its decadal change for Lake Nam Co, central Tibetan Plateau, J. Geophys. Res.-Atmos., 121, 7578-7591, 2016.

Lehmkuhl, F., Klinge, M., and Lang, A.: Late Quaternary glacier advances, lake level fluctuations and aeolian sedimentation in Southern Tibet, Z. Geomorphol. Supp., 126, 183-218, 2002.

Lei, F., Qu, Y., and Song, G.: Species diversification and phylogeographical patterns of birds in response to the uplift of the Qinghai-Tibet Plateau and Quaternary glaciations, Curr. Zool., 60, 149-161, 2014.

Lei, Y., Yao, T., Bird, B. W., Yang, K., Zhai, J., and Sheng, Y.: Coherent lake growth on the central Tibetan Plateau since the 1970s: Characterization and attribution, J. Hydrol., 483, 61-67, https://doi.org/10.1016/j.jhydrol.2013.01.003, 2013.

Li, B., Jing, K., Zhang, Q., Yang, Y., Yin, Z., and Wang, F.: Formation and Evolution of the Drainage Systems in Xizang Area, Beijing, 9 pp., 1981.

Li, G. and Lin, H.: Recent decadal glacier mass balances over the Western Nyainqentanglha Mountains and the increase in their melting contribution to Nam Co Lake measured by differential bistatic SAR interferometry, Global Planet. Change, 149, 177190, https://doi.org/10.1016/j.gloplacha.2016.12.018, 2017.

Li, J., Yan, D., Pendall, E., Pei, J., Noh, N. J., He, J.-S., Li, B., Nie, M., and Fang, C.: Depth dependence of soil carbon temperature sensitivity across Tibetan permafrost regions, Soil Biol. Biochem., 126, 82-90, 2018.

Li, M., Kang, S., Zhu, L., You, Q., Zhang, Q., and Wang, J.: Mineralogy and geochemistry of the Holocene lacustrine sediments in Nam Co, Tibet, Quaternary Int., 187, 105-116, 2008 a.

Li, Q.: Spatial variability and long-term change in pollen diversity in Nam Co catchment (central Tibetan Plateau): Implications for alpine vegetation restoration from a paleoecological perspective, Sci. China Earth Sci., 61, 270-284, https://doi.org/10.1007/s11430-017-9133-0, 2018.

Li, Q., Lu, H., Zhu, L., Wu, N., Wang, J., and Lu, X.: Pollen-inferred climate changes and vertical shifts of alpine vegetation belts on the northern slope of the Nyainqentanglha Mountains (central Tibetan Plateau) since 8.4 kyr BP, The Holocene, 21, 939-950, https://doi.org/10.1177/0959683611400218, 2011.
Li, X. and Cheng, G.: A GIS-aided response model of high-altitude permafrost to global change, Sci. China Ser. D, 42, 72-79, https://doi.org/10.1007/BF02878500, 1999.

Li, Y., Luo, T., and Lu, Q.: Plant height as a simple predictor of the root to shoot ratio: Evidence from alpine grasslands on the Tibetan Plateau, J. Veg. Sci., 19, 245-252, https://doi.org/10.3170/2007-8-18365, 2008b.

Liao, J., Shen, G., and Li, Y.: Lake variations in response to climate change in the Tibetan Plateau in the past 40 years, Int. J. Digit. Earth, 6, 534-549, https://doi.org/10.1080/17538947.2012.656290, 2013.

Liu, S., Schleuss, P.-M., and Kuzyakov, Y.: Carbon and Nitrogen Losses from Soil Depend on Degradation of Tibetan Kobresia Pastures, Land Degrad. Develop., 28, 1253-1262, https://doi.org/10.1002/ldr.2522, 2017a.

Liu, W.-S., Dong, M., Song, Z.-P., and Wei, W.: Genetic diversity pattern of Stipa purpurea populations in the hinterland of Qinghai-Tibet Plateau, Ann. Appl. Biol., 154, 57-65, https://doi.org/10.1111/j.1744-7348.2008.00274.x, 2009.

Liu, Y., Fan, J., Shi, Z., Yang, X., and Harris, W.: Relationships between plateau pika (Ochotona curzoniae) densities and biomass and biodiversity indices of alpine meadow steppe on the Qinghai-Tibet Plateau China, Ecol. Eng., 102, 509-518, https://doi.org/10.1016/j.ecoleng.2017.02.026, 2017b.

López-Pujol, J., Zhang, F.-M., Sun, H.-Q., Ying, T.-S., and Ge, S.: Centres of plant endemism in China: places for survival or for speciation?, J. Biogeogr., 38, 1267-1280, 2011.

Ma, N., Szilagyi, J., Niu, G.-Y., Zhang, Y., Zhang, T., Wang, B., and Wu, Y.: Evaporation variability of Nam Co Lake in the Tibetan Plateau and its role in recent rapid lake expansion, J. Hydrol., 537, 27-35, https://doi.org/10.1016/j.jhydrol.2016.03.030, 2016.

Ma, Y., Wang, Y., Wu, R., Hu, Z., Yang, K., Li, M., Ma, W., Zhong, L., Sun, F., Chen, X., Zhu, Z., Wang, S., and Ishikawa, H.: Recent advances on the study of atmosphere-land interaction observations on the Tibetan Plateau, Hydrol. Earth Syst. Sci., 13, 1103-1111, https://doi.org/10.5194/hess-13-1103-2009, 2009.

Miehe, G., Bach, K., Miehe, S., Kluge, J., Yongping, Y., La Duo, Co, S., and Wesche, K.: Alpine steppe plant communities of the Tibetan highlands, Appl. Veg. Sci., 14, 547-560, https://doi.org/10.1111/j.1654-109X.2011.01147.x, 2011a.

Miehe, G., Miehe, S., Bach, K., Nölling, J., Hanspach, J., Reudenbach, C., Kaiser, K., Wesche, K., Mosbrugger, V., Yang, Y. P., and Ma, Y.: Plant communities of central Tibetan pastures in the Alpine Steppe/Kobresia pygmaea ecotone, J. Arid Environ., 75 , 711-723, https://doi.org/10.1016/j.jaridenv.2011.03.001, $2011 \mathrm{~b}$.

Miehe, G., Miehe, S., Böhner, J., Kaiser, K., Hensen, I., Madsen, D., Liu, J., and Opgenoorth, L.: How old is the human footprint in the world's largest alpine ecosystem? A review of multiproxy records from the Tibetan Plateau from the ecologists' viewpoint, Quaternary Sci. Rev., 86, 190-209, https://doi.org/10.1016/j.quascirev.2013.12.004, 2014

Miehe, G., Miehe, S., Kaiser, K., Jianquan, L., and Zhao, X.: Status and Dynamics of the Kobresia pygmaea Ecosystem on the Tibetan Plateau, AMBIO, 37, 272-279, https://doi.org/10.1579/00447447(2008)37[272:SADOTK]2.0.CO;2, 2008.

Miehe, G., Miehe, S., Schlütz, F., Kaiser, K., and La Duo: Palaeoecological and experimental evidence of former forests and woodlands in the treeless desert pastures of Southern Tibet 
(Lhasa, A.R. Xizang, China), Palaeogeogr. Palaeocl., 242, 5467, https://doi.org/10.1016/j.palaeo.2006.05.010, 2006.

Miehe, G., Schleuss, P.-M., Seeber, E., Babel, W., Biermann, T., Braendle, M., Chen, F., Coners, H., Foken, T., Gerken, T., Graf, H.-F., Guggenberger, G., Hafner, S., Holzapfel, M., Ingrisch, J., Kuzyakov, Y., Lai, Z., Lehnert, L., Leuschner, C., Li, X., Liu, J., Liu, S., Ma, Y., Miehe, S., Mosbrugger, V., Noltie, H. J., Schmidt, J., Spielvogel, S., Unteregelsbacher, S., Wang, Y., Willinghöfer, S., Xu, X., Yang, Y., Zhang, S., Opgenoorth, L., and Wesche, K.: The Kobresia pygmaea ecosystem of the Tibetan highlands - Origin, functioning and degradation of the world's largest pastoral alpine ecosystem: Kobresia pastures of Tibet, Sci. Total Environ., 648, 754-771, https://doi.org/10.1016/j.scitotenv.2018.08.164, 2019.

Mischke, S.: Quaternary Ostracods from the Tibetan Plateau and Their Significance for Environmental and Climate-Change Studies, in: Ostracoda as proxies for Quaternary climate change, 1st Edn., edited by: Horne, D. J., Developments in Quaternary Sciences, 17, Elsevier, Amsterdam, 263-279, 2012.

Mosbrugger, V., Favre, A., Muellner-Riehl, A., Päckert, M., and Mulch, A.: Cenozoic evolution of geo-biodiversity in the TibetoHimalayan region, 429 pp., 2018.

Nan, Z.: Prediction of permafrost distribution on the Qinghai-Tibet Plateau in the next 50 and 100 years, Sci. China Ser. D, 48, 797804, https://doi.org/10.1360/03yd0258, 2005.

Nölling, J.: Satellitenbildgestützte Vegetationskartierung von Hochweidegebieten des Tibetischen Plateaus auf Grundlage von plotbasierten Vegetationsaufnahmen mit multivariater statistischer Analyse: Ein Beitrag zum Umweltmonitoring, Diplomarbeit, Fachbereich Geographie, Universität Marburg, Marburg, 159 pp., 2006.

Oheimb, P. V. von, Albrecht, C., Riedel, F., Bössneck, U., Zhang, H., and Wilke, T.: Testing the role of the Himalaya Mountains as a dispersal barrier in freshwater gastropods (Gyraulus spp.), Biol. J. Linn. Soc. Lond., 109, 526-534, https://doi.org/10.1111/bij.12068, 2013.

Oheimb, P. V. von, Albrecht, C., Riedel, F., Du, L., Yang, J., Aldridge, D. C., Bößneck, U., Zhang, H., and Wilke, T.: Freshwater biogeography and limnological evolution of the tibetan plateau - insights from a plateau-wide distributed gastropod taxon (Radix spp.), PloS One, 6, e26307, https://doi.org/10.1371/journal.pone.0026307, 2011.

Ohtsuka, T., Hirota, M., Zhang, X., Shimono, A., Senga, Y., Du, M., Yonemura, S., Kawashima, S., and Tang, Y.: Soil organic carbon pools in alpine to nival zones along an altitudinal gradient (4400-5300 m) on the Tibetan Plateau, Polar Sci., 2, 277-285, https://doi.org/10.1016/j.polar.2008.08.003, 2008.

Päckert, M., Martens, J., Sun, Y.-H., and Tietze, D. T.: Evolutionary history of passerine birds (Aves: Passeriformes) from the Qinghai-Tibetan plateau: From a pre-Quarternary perspective to an integrative biodiversity assessment, J. Ornithol., 156, 355365,2015

Pepin, N., Bradley, R. S., Diaz, H. F., Baraër, M., Caceres, E. B., Forsythe, N., Fowler, H., Greenwood, G., Hashmi, M. Z., and Liu, X. D.: Elevation-dependent warming in mountain regions of the world, Nat. Clim. Change, 5, 424-430, https://doi.org/10.1038/nclimate2563, 2015.

Qiu, J.: China: The third pole, Nature, 454, 393-396, https://doi.org/10.1038/454393a, 2008.
Qu, B., Sillanpää, M., Li, C., Kang, S., Stubbins, A., Yan, F., Aho, K. S., Zhou, F., and Raymond, P. A.: Aged dissolved organic carbon exported from rivers of the Tibetan Plateau, PloS One, 12, e0178166, https://doi.org/10.1371/journal.pone.0178166, 2017.

R Core Team: R: A Language and Environment for Statistical Computing, Vienna, Austria, available at: https://www.R-project.org/ (last access: 4 March 2020), 2019.

Renner, S. S.: Available data point to a 4-km-high Tibetan Plateau by $40 \mathrm{Ma}$, but 100 molecular-clock papers have linked supposed recent uplift to young node ages, J. Biogeogr., 43, 1479-1487, https://doi.org/10.1111/jbi.12755, 2016.

RStudio Team: RStudio: Integrated Development Environment for R, Boston, MA, http://www.rstudio.com/ (last access: 4 March 2020), 2018.

Schlütz, F., Miehe, G., and Lehmkuhl, F.: Zur Geschichte des größten alpinen Ökosystems der Erde: Palynologische Untersuchungen zu den Kobresia-Matten SE-Tibets, Reinhardt Tüxen gesellschaft, Hannover, 19, 14 pp., 2007.

Schütt, B., Berking, J., Frechen, M., Frenzel, P., Schwalb, A., and Wrozyna, C.: Late Quaternary transition from lacustrine to a fluvio-lacustrine environment in the north-western Nam Co, Tibetan Plateau, China, Quaternary Int., 218, 104-117, https://doi.org/10.1016/j.quaint.2009.05.009, 2010.

Shangguan, D. H., Liu, S. Y., Ding, L. F., Zhang, S.-q., Li, G., Zhang, Y., and Li, J.: Variation of glaciers in the Western Nyainqêntanglha range of Tibetan Plateau during 1970-2000, J. Glaciol. Geocryol., 30, 204-210, 2008.

Simpson, J. R., Cheng, X., and Miyazaki, A.: China's livestock and related agriculture: Projections to 2025, CAB Internat, Wallingford, 474 pp., 1994.

Smith, J. R., Letten, A. D., Ke, P.-J., Anderson, C. B., Hendershot, J. N., Dhami, M. K., Dlott, G. A., Grainger, T. N., Howard, M. E., Morrison, B.M.L., Routh, D., San Juan, P. A., Mooney, H. A., Mordecai, E. A., Crowther, T. W., and Daily, G. C.: A global test of ecoregions, Nat. Ecol. Evol., 2, 1889-1896, https://doi.org/10.1038/s41559-018-0709-x, 2018.

Spencer, R. G. M., Guo, W., Raymond, P. A., Dittmar, T., Hood, E., Fellman, J., and Stubbins, A.: Source and biolability of ancient dissolved organic matter in glacier and lake ecosystems on the Tibetan Plateau, Geochim. Cosmochim. Ac., 142, 64-74, https://doi.org/10.1016/j.gca.2014.08.006, 2014.

Tian, K., Liu, J., Kang, S., Campbell, I. B., Zhang, F., Zhang, Q., and $\mathrm{Lu}, \mathrm{W} .:$ Hydrothermal pattern of frozen soil in Nam Co lake basin, the Tibetan Plateau, Environ. Geol., 57, 1775-1784, https://doi.org/10.1007/s00254-008-1462-2, 2009.

Unteregelsbacher, S., Hafner, S., Guggenberger, G., Miehe, G., $\mathrm{Xu}, \mathrm{X}$. , Liu, J., and Kuzyakov, Y.: Response of long-, mediumand short-term processes of the carbon budget to overgrazinginduced crusts in the Tibetan Plateau, Biogeochemistry, 111, 187-201, https://doi.org/10.1007/s10533-011-9632-9, 2012.

Velde, B.: Structure of surface cracks in soil and muds, Geoderma, 93, 101-124, https://doi.org/10.1016/S0016-7061(99)00047-6, 1999.

Vivian-Smith, G.: Microtopographic Heterogeneity and Floristic Diversity in Experimental Wetland Communities, J. Ecol., 85, 71-82, https://doi.org/10.2307/2960628, 1997.

Voelker, G., Semenov, G., Fadeev, I. V., Blick, A., and Drovetski, S. V.: The biogeographic history of Phoenicurus redstarts reveals 
an allopatric mode of speciation and an out-of-Himalayas colonization pattern, Syst. Biodivers., 13, 296-305, 2015.

Walther, G.-R., Post, E., Convey, P., Menzel, A., Parmesan, C., Beebee, T. J. C., Fromentin, J.-M., Hoegh-Guldberg, O., and Bairlein, F.: Ecological responses to recent climate change, Nature, 416, 389-395, https://doi.org/10.1038/416389a, 2002.

Wang, G., Qian, J., Cheng, G., and Lai, Y.: Soil organic carbon pool of grassland soils on the Qinghai-Tibetan Plateau and its global implication, Sci. Total Environ., 291, 207-217, https://doi.org/10.1016/S0048-9697(01)01100-7, 2002.

Wang, G., Wang, Y., Li, Y., and Cheng, H.: Influences of alpine ecosystem responses to climatic change on soil properties on the Qinghai-Tibet Plateau, China, CATENA, 70, 506-514, https://doi.org/10.1016/j.catena.2007.01.001, 2007.

Wang, J., Zhu, L., Daut, G., Ju, J., Lin, X., Wang, Y., and Zhen, $X$. Investigation of bathymetry and water quality of Lake Nam $\mathrm{Co}$, the largest lake on the central Tibetan Plateau, China, Limnology, 10, 149-158, https://doi.org/10.1007/s10201-009-02668, 2009a.

Wang, L.: Meteorological observation data of Namuco multi circle comprehensive observation and research station (2017-2018), National Tibetan Plateau Data Center, available at: https://data. tpdc.ac.cn/en/data/3767cacc-96e3-48b2-b66c-dac92800ca69/ (last access: 4 March 2020), 2019.

Wang, L., Liu, H., Shao, Y., Liu, Y., and Sun, J.: Water and $\mathrm{CO}_{2}$ fluxes over semiarid alpine steppe and humid alpine meadow ecosystems on the Tibetan Plateau, Theor. Appl. Climatol., 131, 547-556, https://doi.org/10.1007/s00704-016-1997-1, 2018a.

Wang, L. and Yi, C.: Properties and periglacial processes in alpine meadow soils, western Nyainqentanglha Mountains, Tibet, Quaternary Int., 236, 65-74, https://doi.org/10.1016/j.quaint.2010.06.003, 2011.

Wang, L., Yi, C., Xu, X., Schütt, B., Liu, K., and Zhou, L.: Soil properties in two soil profiles from terraces of the Nam Co Lake in Tibet, China, J. Mt. Sci., 6, 354-361, https://doi.org/10.1007/s11629-009-1017-3, 2009b.

Wang, R., Yang, X., Langdon, P., and Zhang, E.: Limnological responses to warming on the Xizang Plateau, Tibet, over the past 200 years, J. Paleolimnol., 45, 257-271, https://doi.org/10.1007/s10933-011-9496-y, 2011.

Wang, X., Siegert, F., Zhou, A.-G., and Franke, J.: Glacier and glacial lake changes and their relationship in the context of climate change, Central Tibetan Plateau 1972-2010, Glob. Planet. Change, 111, 246-257, https://doi.org/10.1016/j.gloplacha.2013.09.011, 2013.

Wang, X., Wang, Y., Li, Q., Tseng, Z. J., Takeuchi, G. T., Deng, T., Xie, G., Chang, M.-M., and Wang, N.: Cenozoic vertebrate evolution and paleoenvironment in Tibetan Plateau: Progress and prospects, Gondwana Res., 27, 1335-1354, 2015.

Wang, Y., Lehnert, L. W., Holzapfel, M., Schultz, R., Heberling, G., Görzen, E., Meyer, H., Seeber, E., Pinkert, S., Ritz, M., Fu, Y., Ansorge, H., Bendix, J., Seifert, B., Miehe, G., Long, R.-J., Yang, Y.-P., and Wesche, K.: Multiple indicators yield diverging results on grazing degradation and climate controls across Tibetan pastures, Ecol. Indic., 93, 1199-1208, https://doi.org/10.1016/j.ecolind.2018.06.021, 2018b.

Wang, Y. and Wesche, K.: Vegetation and soil responses to livestock grazing in Central Asian grasslands: a review of Chinese literature, Biodivers. Conserv., 25, 2401-2420, https://doi.org/10.1007/s10531-015-1034-1, 2016.

Wang, Y. and $\mathrm{Wu}, \mathrm{G} .:$ Meteorological observation data from the integrated observation and research station of multiple spheres in Namco (2005-2016), National Tibetan Plateau Data Center, https://doi.org/10.11888/AtmosPhys.tpe.00000049.file, 2018.

Wang, Y., Zhu, L. P., Wang, J. B., Ju, J. T., and Lin, X.: The spatial distribution and sedimentary processes of organic matter in surface sediments of Nam Co, Central Tibetan Plateau, Chin. Sci. Bull., 57, 4753-4764, https://doi.org/10.1007/s11434-012-55009, 2012

Wei, D., Xu, R., Tenzin, T., Wang, Y., and Wang, Y.: Considerable methane uptake by alpine grasslands despite the cold climate: in situ measurements on the central Tibetan Plateau, 2008-2013, Glob. Change Biol., 21, 777-788, https://doi.org/10.1111/gcb.12690, 2015.

Wickham, H.: tidyverse: Easily Install and Load the "Tidyverse", available at: https://CRAN.R-project.org/package=tidyverse (last access: 4 March 2020), 2017.

Wrozyna, C., Frenzel, P., Daut, G., Mäusbacher, R., Zhu, L., and Schwalb, A.: Holocene Lake-Level Changes of Lake Nam Co, Tibetan Plateau, Deduced from Ostracod Assemblages and $\delta^{18} \mathrm{O}$ and $\delta^{13} \mathrm{C}$ Signatures of Their Valves, Dev. Quaternary Sci., 17, 281 pp., 2012.

Wrozyna, C., Frenzel, P., Steeb, P., Zhu, L., van Geldern, R., Mackensen, A., and Schwalb, A.: Stable isotope and ostracode species assemblage evidence for lake level changes of Nam Co, southern Tibet, during the past 600 years, Quaternary Int., 212, 2-13, https://doi.org/10.1016/j.quaint.2008.12.010, 2010.

Wu, K., Liu, S., Guo, W., Wei, J., Xu, J., Bao, W., and Yao, X.: Glacier change in the western Nyainqentanglha Range Tibetan Plateau using historical maps and Landsat imagery, J. Mt. Sci., 13, 1358-1374, 2016.

Wu, Q., Zhang, T., and Liu, Y.: Permafrost temperatures and thickness on the Qinghai-Tibet Plateau, Glob. Planet. Change, 72, 3238, https://doi.org/10.1016/j.gloplacha.2010.03.001, 2010.

Wu, Y., Zheng, H., Zhang, B., Chen, D., and Lei, L.: Long-Term Changes of Lake Level and Water Budget in the Nam Co Lake Basin, Central Tibetan Plateau, J. Hydrometeor., 15, 1312-1322, https://doi.org/10.1175/JHM-D-13-093.1, 2014.

$\mathrm{Wu}, \mathrm{Y}$. and $\mathrm{Zhu}, \mathrm{L}$.: The response of lake-glacier variations to climate change in Nam Co Catchment, central Tibetan Plateau, during 1970-2000, J. Geogr. Sci., 18, 177-189, https://doi.org/10.1007/s11442-008-0177-3, 2008.

Wünnemann, B., Yan, D., Andersen, N., Riedel, F., Zhang, Y., Sun, Q., and Hoelzmann, P.: A $14 \mathrm{ka}$ high-resolution $\delta^{18} \mathrm{O}$ lake record reveals a paradigm shift for the processbased reconstruction of hydroclimate on the northern Tibetan Plateau, Quaternary Sci. Rev., 200, 65-84, https://doi.org/10.1016/j.quascirev.2018.09.040, 2018.

Yan, Y., Ganjurjav, H., Hu, G., Liang, Y., Li, Y., He, S., Danjiu, L., Yang, J., and Gao, Q.: Nitrogen deposition induced significant increase of $\mathrm{N}_{2} \mathrm{O}$ emissions in an dry alpine meadow on the central Qinghai-Tibetan Plateau, Agriculture, Ecosyst. Environ. 265, 45-53, https://doi.org/10.1016/j.agee.2018.05.031, 2018.

Yang, M., Wang, S., Yao, T., Gou, X., Lu, A., and Guo, X.: Desertification and its relationship with permafrost degradation in Qinghai-Xizang (Tibet) plateau, Cold Reg. Sci. Technol., 39, 4753, https://doi.org/10.1016/j.coldregions.2004.01.002, 2004. 
Yang, S., Dong, H., and Lei, F.: Phylogeography of regional fauna on the Tibetan Plateau: a review, Prog. Nat. Sci., 19, 789-799, 2009.

Yao, T., Masson-Delmotte, V., Gao, J., Yu, W., Yang, X., Risi, C., Sturm, C., Werner, M., Zhao, H., He, Y., Ren, W., Tian, L., Shi, C., and Hou, S.: A review of climatic controls on $\delta 18 \mathrm{O}$ in precipitation over the Tibetan Plateau: Observations and simulations, Rev. Geophys., 51, 525-548, https://doi.org/10.1002/rog.20023, 2013.

Yao, T., Pu, J., Lu, A., Wang, Y., and Yu, W.: Recent Glacial Retreat and Its Impact on Hydrological Processes on the Tibetan Plateau, China, and Surrounding Regions, Arctic, Antarctic Alpine Res., 39, 642-650, https://doi.org/10.1657/15230430(07-510)[YAO]2.0.CO;2, 2007.

Yingfang, C., Xun, K., Xiaowei, G., Guangmin, C., and Du Yangong: Nitrous Oxide Emission Rates over 10 Years in an Alpine Meadow on the Tibetan Plateau, Pol. J. Environ. Stud., 27, 13531358, https://doi.org/10.15244/pjoes/76795, 2018.

Yu, F.-H., Li, P.-X., Li, S.-L., and He, W.-M.: Kobresia tibetica tussocks facilitate plant species inside them and increase diversity and reproduction, Basic Appl. Ecol., 11, 743-751, https://doi.org/10.1016/j.baae.2010.09.005, 2010.

Zhang, B., Wu, Y., Zhu, L., Wang, J., Li, J., and Chen, D.: Estimation and trend detection of water storage at Nam Co Lake, central Tibetan Plateau, J. Hydrol., 405, 161-170, https://doi.org/10.1016/j.jhydrol.2011.05.018, 2011.

Zhang, G., Li, J., and Zheng, G.: Lake-area mapping in the Tibetan Plateau: an evaluation of data and methods, Int. J. Remote Sens., 38, 742-772, https://doi.org/10.1080/01431161.2016.1271478, 2017.

Zhang, P., Chen, Y.-Q., Zhou, H., Liu, Y.-F., Wang, X.-L., Papenfuss, T. J., Wake, D. B., and Qu, L.-H.: Phylogeny, evolution, and biogeography of Asiatic Salamanders (Hynobiidae), P. Natl. Acad. Sci. USA, 103, 7360-7365, 2006.

Zhang, T., Zhang, Y., Xu, M., Zhu, J., Chen, N., Jiang, Y., Huang, K., Zu, J., Liu, Y., and Yu, G.: Water availability is more important than temperature in driving the carbon fluxes of an alpine meadow on the Tibetan Plateau, Agr. Forest Meteorol., 256-257, 22-31, https://doi.org/10.1016/j.agrformet.2018.02.027, 2018.

Zhao, J., Li, R., Li, X., and Tian, L.: Environmental controls on soil respiration in alpine meadow along a large altitudinal gradient on the central Tibetan Plateau, CATENA, 159, 84-92, https://doi.org/10.1016/j.catena.2017.08.007, 2017.
Zhao, J., Luo, T., Li, R., Wei, H., Li, X., Du, M., and Tang, Y.: Precipitation alters temperature effects on ecosystem respiration in Tibetan alpine meadows, Agr. Forest Meteorol., 252, 121-129, https://doi.org/10.1016/j.agrformet.2018.01.014, 2018.

Zhou, H., Zhao, X., Tang, Y., Gu, S., and Zhou, L.: Alpine grassland degradation and its control in the source region of the Yangtze and Yellow Rivers, China, Grassl. Sci., 51, 191-203, https://doi.org/10.1111/j.1744-697X.2005.00028.x, 2005.

Zhou, S., Kang, S., Chen, F., and Joswiak, D. R.: Water balance observations reveal significant subsurface water seepage from Lake Nam Co, south-central Tibetan Plateau, J. Hydrol., 491, 89-99, https://doi.org/10.1016/j.jhydrol.2013.03.030, 2013.

Zhou, Y., Jiao, S., Li, N., Grace, J., Yang, M., Lu, C., Geng, X., Zhu, X., Zhang, L., and Lei, G.: Impact of plateau pikas (Ochotona curzoniae) on soil properties and nitrous oxide fluxes on the Qinghai-Tibetan Plateau, PloS One, 13, e0203691, https://doi.org/10.1371/journal.pone.0203691, 2018.

Zhu, D., Xitao, Z., Xiangang, M., Zhonghai, W. U., Zhenhan, W. U., Xiangyang, F., Zhaogang, S., Qisheng, L. I. U., and Meiling, Y.: Quaternary Lake Deposits of Nam Co, Tibet, with a Discussion of the Connection of Nam Co with Ring Co-Jiuru Co, Acta Geologica Sinica - English Edition, 76, 283-291, https://doi.org/10.1111/j.1755-6724.2002.tb00544.x, 2002.

Zhu, L., Lü, X., Wang, J., Peng, P., Kasper, T., Daut, G., Haberzettl, T., Frenzel, P., Li, Q., Yang, R., Schwalb, A., and Mäusbacher, R.: Climate change on the Tibetan Plateau in response to shifting atmospheric circulation since the LGM, Sci. Rep., 5, 13318, https://doi.org/10.1038/srep13318, 2015a.

Zhu, L., Peng, P., Xie, M., Wang, J., Frenzel, P., Wrozyna, C., and Schwalb, A.: Ostracod-based environmental reconstruction over the last 8,400 years of Nam Co Lake on the Tibetan plateau, Hydrobiologia, 648, 157-174, https://doi.org/10.1007/s10750-0100149-3, 2010a.

Zhu, L., Xie, M., and Wu, Y.: Quantitative analysis of lake area variations and the influence factors from 1971 to 2004 in the Nam Co basin of the Tibetan Plateau, Chin. Sci. Bull., 55, 1294-1303, https://doi.org/10.1007/s11434-010-0015-8, 2010b.

Zhu, Z., Ma, Y., Li, M., Hu, Z., Xu, C., Zhang, L., Han, C., Wang, Y., and Ichiro, T.: Carbon dioxide exchange between an alpine steppe ecosystem and the atmosphere on the Nam Co area of the Tibetan Plateau, Agr. Forest Meteorol., 203, 169-179, https://doi.org/10.1016/j.agrformet.2014.12.013, 2015b. 